Reprod. Nutr. Dévelop., 1981, 21 (2), 209-235.

\title{
Le contrôle de la synthèse protéique dans les cellules des eucaryotes
}

par L.-M. HOUDEBINE

Laboratoire de Physiologie de la Lactation, I.N.R.A., 78350 jouy en josas, France.

Summary. Control of protein synthesis in eukaryote cells.

In the present report, the following aspects of the control of gene expression in eukaryote cells has been reviewed :1) the mechanism of mRNA formation in relation to recent findings on introns in genes ; 2 ) the correlation between the concentration of mRNAs in cells and the rate of synthesis of the related proteins ; 3) the control of specific transcription ; 4) the stabilization of specific mRNAs ; 5) the involvement of genome rearrangement as a possible mode of controlling gene expression ; 6) the mechanism of hormonal control of specific gene expression.

La régulation de la synthèse des protéines est un des mécanismes les plus importants dans le processus de développement. Ceci tient évidemment au fait que les protéines ont dans la cellule des fonctions essentielles et variées : protéines enzymatiques, protéines structurales, protéines de sécrétion (protéines de l'œuf, protéines du lait, immunoglobulines, sérumalbumine, hormones, etc...). Cette multiplicité laisse supposer que les mécanismes moléculaires de la régulation de l'expression de divers gènes en protéines sont eux-mêmes multiples. Dans la plupart des cas, une altération du taux de synthèse d'une protéine a pour but de répondre àune sollicitation extérieure, c'est dire qu'elle résulte d'un échange d'information entre la cellule et son environnement. Cet échange est lui-même assuré par l'intermédiaire de messages de nature variée (hormones, vitamines, co-facteurs, métabolites, facteurs de croissance, ions, efc...). L'étude de la régulation de la synthèse des protéines s'entend donc comme devant comprendre l'ensemble des mécanismes cellulaires et moléculaires impliqués dans la perception de l'information extracellulaire et la synthèse protéique proprement dife. Le présent rapport ne saurait prétendre considérer la totalité des données relatives à ces questions dont la masse est écrasante. Ce sont préférentiellement certains aspects ayant reçu un intense développement ces dernières années que nous envisagerons en nous limiłant volontairement aux étapes précédant l'assemblage des acides aminés en polypeptides qui est traité conjointement dans un autre rapport (Pétrissant, 1981). 


\section{I. - Les mécanismes de la formation des RNA messagers.}

Le schéma de biosynthèse des protéines défini chez les bactéries, comprenant un attachement des ribosomes au RNA messager naissant au fur et à mesure de l'élongation de la chaîne polynucléotidique et impliquant donc un couplage entre la transcription des gènes ef la traduction des RNA messagers en proféines, ne saurait être étendu aux cellules des eucaryotes. Plusieurs raisons s'opposent à une telle généralisation. C'est tout d'abord le fait qu'il existe une ségrégation spatiale entre les gènes concentrés dans le noyau et les ribosomes localisés essentiellement dans le cytoplasme. Cette ségrégation interdit évidemment l'amorce d'une abondante synthèse protéique à partir du RNA messager naissant, et en retour, elle permet vraisemblablement uné modulation du transfert de l'information extracellulaire qui doit traverser la membrane plasmique, le cytoplasme, la membrane nucléaire et les structures intranucléaires avant d'atteindre les gènes. Par ailleurs, un couplage entre transcription et traduction suppose qu'une régulation de l'expression génétique dans les étapes traductionnelles n'est pas déterminante. Les cellules des eucaryofes sont manifestement loin de n'avoir choisi qu'un seul point de contrôle pour la synthèse des protéines. Cela tient peut-être en partie au fait qu'il existe beaucoup plus de gènes à contrôler chez les organismes supérieures que chez les micro-organismes, et qu'il est peut-être plus simple et plus sût de multiplier les interventions des systèmes régulateurs (Scherrer, 1973). D'autre part, les cellules des organismes pluricellulaires évolués étant spécialisées, donc soumises à une pression d'adaptation à des situations nouvelles limitée, on peut concevoir qu'il ne soit pas nécessaire, pour moduler la synthèse d'une protéine, d'avoir nécessairement recours à l'activation de la transcription du gène correspondant.

\section{A. - Le découpage des gènes en introns et exons.}

Un des traits essentiels qui paraît maintenant devoir différencier les organismes des procaryotes de ceux des eucaryotes réside dans la structure même des gènes et des RNA messagers. Bon nombre de gènes comportent en effet au sein même des portions codant pour la protéine correspondante (exons), des séquences plus ou moins longues (introns) ne codant pas pour la protéine (Breathnach et al., 1977 ; Jeffryes et Flavell, 1977 ; Gilbert, 1978 ; Crick, 1979 ; Kolata, 1980). Ces séquences sont transcrifes intégralement semble-t-il pour former le pré-RNA messager. Les introns sont alors éliminés par un mécanisme d'excision-épissage comportant des coupures du pré-RNA messager en des points bien précis, définis en partie par une séquence nucléotidique environnant le site de coupure. Ces coupures sont suivies d'une soudure des parties codantes conduisant à l'élaboration de la séquence nucléotidique définitive codant pour la protéine. L'ordre des exons est le même dans le pré-RNA messager et dans le RNA messager mature (O'Hare et al., 1979) (fig. 1). Le mécanisme de coupure du pré-RNA messager et d'association des exons n'a pas encore été élucidé. Il semble toutefois que, dans la plupart des cas étudiés, il soit possible de reconnaître une séquence privilégiée qui pourraił constituer des sites de reconnaissance pour les enzymes assurant l'élaboration du RNA messager dans sa forme définitive (fig. 2). Cette modification n'est toutefois pas la seule que doit subir le pré-RNA messager pour 


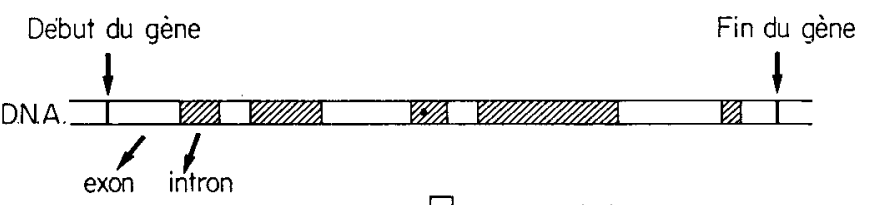

\section{Transcription}

$5^{\prime} P$ pré-mRNA
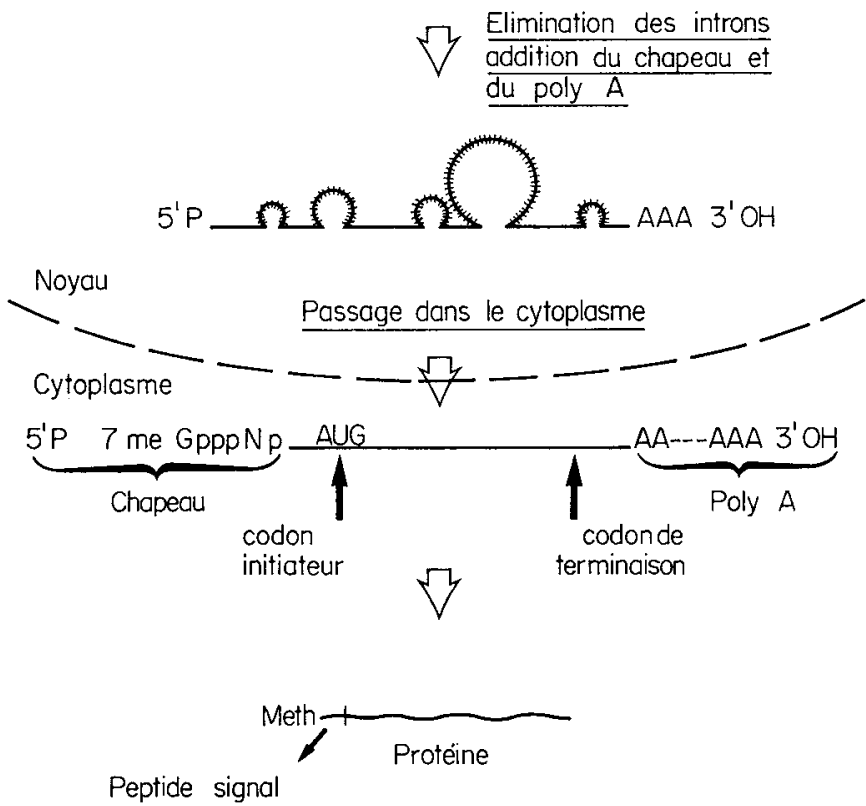

FIG. 1. - Schéma de la biosynthèse, de la maturation et du passage dans le cytoplasme des RNA messagers.

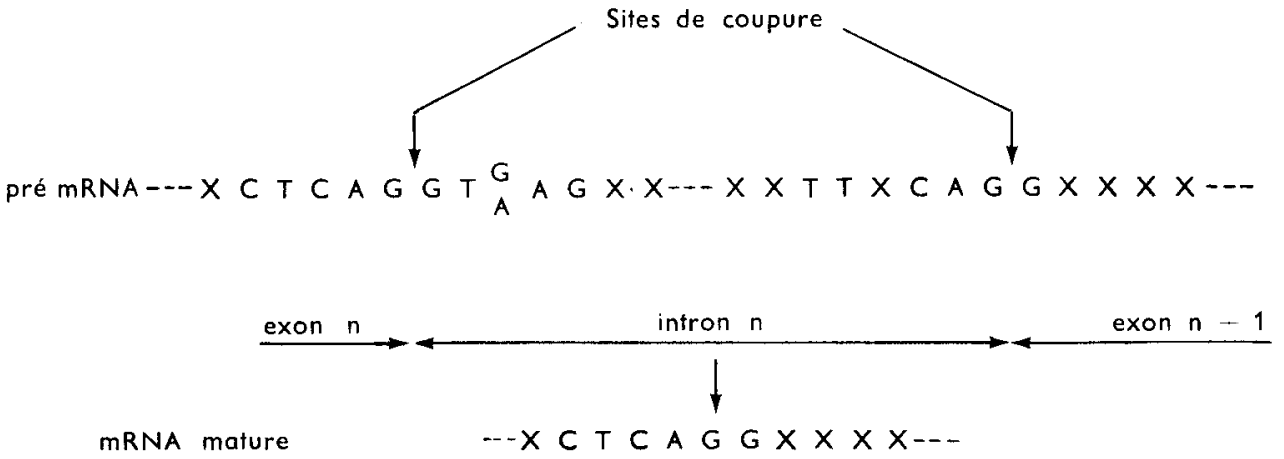

FIG. 2. - Séquence consensus au voisinage des sites de coupure exon-intron et des sifes d'épissage des exons (Dawid et Wahli, 1979). 
devenir fonctionnel dans le cytoplasme. La partie 5' P terminale se voit en effet dotée d'une courte séquence nucléotidique ou « chapeau » qui semble protéger le RNA messager contre les activités nucléasiques et qui est de plus en plus impliqué dans le mścanisme d'initiation de la traduction du message en protéine (Kozak, 1979). A la partie $3^{\prime} \mathrm{OH}$ terminale est par ailleurs ajouté un segment poly A plus ou moins long et dont un des rôles serait de protéger le RNA messager contre des activités nucléasiques (Nudel et al., 1976 ; Hieter et al., 1976). L'addition de ces deux séquences terminales est un phénomène relativement précoce et qui pourrait avoir pris place dans le pré-RNA messager avant même l'excision complète des introns (Ziff et Evans, 1978 ; Salditt-Georgieff et al., 1980). Ce mécanisme de formation des RNA messagers semble actuellement prévaloir sur d'autres dans lesquels les parties non codantes des gènes ne seraient pas transcrites par la RNA polymérase, les morceaux définitifs du RNA messager étant alors synthétisés séparément et assemblés ultérieurement.

Le mécanisme de synthèse des RNA messagers impliquant la formation de préRNA messagers suivie de l'élimination des parties non codantes (Kinniburgh et Ross, 1979) apparaît comme assez généralement répandu el commun à la plupart des cellules des eucaryotes. En effet, lorsque des gènes isolés d'un type cellulaire donné sont introduits directement ou par l'intermédiaire d'un vecteur tel que le SV 40, dans une cellule d'un autre type, ils donnent lieu à une synthèse de la protéine correspondante (Wigler et al., 1977, 1978, 1979 ; Pellicer et al., 1978 ; Wold ef al., 1979 ; Scangos et al., 1979 ; Mantei et al., 1979 ; Hamer et al., 1979 ; Mulligan et al., 1979 ; Hamer et Leder, $1979 b$; Lai ef al., 1980 ; Breathnach et al., 1980).

Ceci implique naturellement que l'essentiel des mécanismes de transcription des gènes ef de maturation des pré-RNA messagers est très voisin d'une cellule à une autre. Notons toutefois que les levures ne paraissent pas posséder tous les éléments nécessaires à l'expression normale du gène de globine de Lapin (Beggs et al., 1980). Les mécanismes enzymatiques impliqués dans les processus de découpage du pré-RNA messager n'ont encore été que très partiellement élucidés. Dans le cas d'une gène de tRNA, il a été possible de procéder à l'excision d'un intron d'un pré-tRNA dans un système acellulaire (Knapp et al., 1978 ; Melton et al., 1980).

Le fait que des introns n'aient jamais pu être mis en évidence dans les gènes des procaryotes a conduit à postuler que les introns (Kolata, 1980 ; Gilbert, 1978) étaient apparus au cours de l'évolution, ou qu'au contraire deux voies relativement indépendantes auraient été suivies par les procaryotes et les eucaryotes (Darnell, 1978 ; Doolittle, 1978). Quoi qu'il en soit, il apparaît maintenant que les gènes d'un organisme possèdent d'autant plus d'introns qu'ils sont plus évolués.

La mise en évidence de l'existence d'interruptions dans la partie exprimée des gènes constitue sans aucun doute une observation qui permet maintenant de poser beaucoup plus précisément les questions se rapportant aux problèmes de l'évolution des gènes et du contrôle de leur expression. Notons tout d'abord que l'existence des introns semble être très largement répandue. Elle a été examinée surtout dans les gènes spécialisés et exprimés en abondance dans la phase ultime de la différenciation cellulaire (ovalbumine, globine, immunoglobuline, lysozyme, ovomucoïde, fibroïne, vitellogénine, etc...). Cette propriété n'est pas pour autant réservée aux gènes spécialisés puisque la gène de la dihydrofolate réductase se trouve être interrompu par de 
nombreux ef longs introns (Nunberg ef al., 1980). Cependant, certains gènes de structure tels que ceux des histones (Schaffner et al, 1978 ; Lifton et al., 1978) ou de l'actine (McKeown et al., 1978) ne sont pas interrompus par des introns (Dawid et Wahli, 1979). Par ailleurs, l'existence d'introns n'est pas strictement réservée aux gènes qui conduisent à la synthèse d'une protéine puisque des interruptions ont été observées dans certains gènes des tRNA (Goodman et al., 1977 ; Valenzuela et al., 1978) et des RNA ribosomaux (Dawid et Wahli). Aucune généralisation ne paraît donc encore possible tant qu'un inventaire plus exhaustif n'aura pas été établi.

\section{B. - Rôle des introns.}

Divers rôles ont d'ores et déjà été attribués aux introns. Leur existence reflète, en partie tout au moins, la longueur considérable du DNA des génômes des eucaryotes (Davidson ef al., 1977) puisque, dans un gène, les introns peuvent représenter jusqu'à dix fois plus de séquences nucléotidiques que les exons. Une explication au moins partielle se trouve également ainsi fournie pour rendre comple de la nature des RNA nucléaires de grande taille et possédant des séquences identiques aux RNA messagers cytoplasmiques (Kwan ef al., 1977 ; Ross, 1976 ; Kinninburgh ef al., 1978 ; Horowitz ef al., 1978 ; Roop et al., 1978, 1980 ; Harpold et al., 1979 ; Scherrer et al., 1979 ; Ryffel et al., 1980). Il a été proposé que l'introduction des introns dans le génôme a éfé un des éléments majeurs des mécanismes de l'évolution au niveau des gènes (Gilbert, 1978 ; Doolittle, 1979 ; Darnell, 1978 ; Crick, 1979). Le fait que les gènes soient fragmentés a dû favoriser les recombinaisons. En effet, la jonction d'un morceau d'intron à un morceau d'un autre intron n'affecte pas pour antant les exons voisins puisque les séquences des introns sont finalement éliminées dans le RNA messager fonctionnel. En particulier, la soudure en un point quelconque de deux fragments d'introns n'introduit pas de décalage de phase dans la lecture des codons des exons, dans la mesure où le site de coupure intron-exon reste inchangé. De telles hypothèses ne semblent pas être que des vues de l'esprit. En effet, la connaissance détaillée de la structure de plusieurs gènes a permis de conclure qu'ils sont bel et bien formés de plusieurs minigènes qui ont dû s'associer lors d'un processus évolutif, pour donner naissance à des gènes plus complexes et ayant une structure stable. De telles possibilités étaient suggérées dans certains cas par la structure des protéines elles-mêmes. Dans d'autres cas, comme celui de la globine, seul un examen de la structure du gène a pu faire apparaître l'existence de 3 zones distinctes séparées par 2 introns (Leder ef al., 1978). Ces domaines correspondent en fait aux propriétés fonctionnelles de la protéine : l'exon central correspond à la portion de la globine liant l'hème, tandis que les 2 exons terminaux sont plutôt impliqués dans les interactions globine-globine (Craik et al., 1980). Une telle fragmentation était d'autant moins prévisible que dans la protéine, la frontière entre les domaines se trouve totalement masquée au sein d'une structure en hélice. De la même façon, les gènes des immunoglobulines sont formés à partir de fragments distincts contenant les parties variables et constantes dans lesquelles on peut reconnaître un domaine de base qui se répète et qui présente de grandes analogies avec la structure de la $\beta_{2}$-microglobuline. Le cas des immunoglobulines a ceci de particulier que les différents domaines se rapprochent pour former de nouveaux gènes au cours de la différenciation cellulaire. Divers modes d'association des différents domaines per- 
mettent ainsi de donner naissance à la variété infinie des anticorps (Seidman et al., 1979). Dans cet ordre d'idée, il est possible que la partie des gènes correspondant au peptide signal hydrophobe situé dans la partie $\mathrm{NH}_{2}$ terminale des protéines sécréfées soit généralement concentrée dans un exon et soit donc séparée du reste du gène. Une telle éventualité pourrait indiquer que ce domaine des protéines est apparu au cours de l'évolution par simple adjonction de ce type d'exon à des gènes préexistants, conférant ainsi aux protéines correspondantes la faculté de pouvoir être sécrétées. Il est raisonnable d'imaginer que de tels processus d'évolution aient pu laisser des traces de gènes inachevés ou ayant en tout cas divergé dans le génôme. La présence de deux gènes présentant de profondes analogies structurales avec le gène de l'ovalbumine dans le génôme de Poulet pourrait représenter de tels résidus de l'évolution (Royal et al., 1979).

Il est remarquable que des protéines comme les histones qui ont subi particulièrement peu de variation au cours de l'évolution soient justement parmi celles dont les gènes ne sont pas interrompus par des introns. On peut également penser que l'absence d'intron dans les gènes des histones est en fait en relation avec le rôle particulier de ces protéines dans les cellules. Les histones sont en effet synthétisées en quantité élevée et pendant une période essentiellement limitée du cycle cellulaire. L'existence d'introns ef la nécessité de mettre en jeu les processus de maturation de leurs RNA messagers ralentiraient peut-être par trop l'induction de la synthèse de ces protéines.

Aussi séduisantes que soient ces propositions, elles ne peuvent être fermement établies tant que seul un nombre réduit de cas aura été examiné. Ainsi, le nombre ef surtout la très petite taille de certains exons, tels que ceux rencontrés dans la gène de la conalbumine (Cochet et al., 1979) paraissent peu compatibles avec l'idée que chaque exon n'est qu'un minigène ayant participé à la formation d'un autre gène plus complexe. Par ailleurs, il est apparu que des gènes normalement pourvus d'introns et dans lesquels des introns avaient été retranchés ne conduisent pas à la formation de RNA messagers stables. Une telle situation a pu être observée dans des mutants du virus SV 40 : les parties du génôme ayant perdu ses introns ne donnent plus les RNA messagers correspondants. De même des fragments de DNA de SV 40 ne conduisent à la formation de RNA messagers stables que si ces fragments contiennent au moins un intron qui peut d'ailleurs tout aussi bien être un des introns du gène de globine (Hamer et Leder, 1979a). De même, seuls les gènes des virus se repliquant dans le noyau semblent posséder des introns par opposition à ceux dont la replication a lieu dans le cyłoplasme. Il a été proposé que les introns pourraient contenir des « séquences guides » qui pourraient participer au positionnement des régions du pré-RNA messager devant être coupées puis soudées (Halbreich et al., 1980). Une autre possibilité serait que les introns codent en fait pour des proféines dont la synthèse a lieu en très faible quantité dans le noyau. Ces protéines serviraient à l'ancrage des pré-RNA messagers à des structures nucléaires impliquées dans la maturation et l'expulsion des RNA-messagers dans le cytoplasme (Slonimski, 1980 ; Jacq et al., 1980). Les séquences interrompant les gènes sont donc impliquées dans certaines étapes du mécanisme conduisant à l'accumulation des RNA messagers fonctionnels dans le cytoplasme. L'absence d'intron dans les gènes des histones et de l'actine interdit là encore toute généralisation. 


\section{II. - Corrélation entre la concentration en RNA messager ef le taux de synthèse des protéines.}

Le célèbre schéma de Jacob et Monod nous a familiarisé avec l'idée que chez les bactéries, le taux de synthèse d'une protéine est réglé essentiellement par la quantité de RNA messagers correspondants disponibles pour l'appareil traductionnel. Un nombre suffisamment grand de cas ont maintenant été examinés pour que l'on puisse considérer que ce mécanisme a été conservé pour l'essentiel dans les cellules des eucaryotes. Dans le tableau 1 sont résumées diverses situations dans lesquelles il existe un parallélisme satisfaisant entre l'accumulation d'un RNA messager et le taux de synthèse de la protéine correspondante et ce, sans distinction de la nature de l'inducteur : hormones stéroïdes, hormones protéiques, thyroxine, acide indolacétique, cAMP, ou facteurs différenciateurs non déterminés. Si la présence d'un nombre suffisant de RNA messagers est évidemment une condition nécessaire pour la synthèse d'une protéine, cette présence à elle seule ne signifie pas que la protéine correspondante est effectivement synthétisée. Dans de nombreux types cellulaires, des RNA messagers non traduits et donc stockés à l'état libre sous forme de particule ribonucléoprotéique ont pu être identifiés (Gédamu ef al., 1977 ; Zähringer et al., 1976a, b, c; Nilsson ef Hultin, 1975 ; Buckingham et Gros, 1975 ; Dym et al., 1979 ; Gédamu et al., 1977 ; Paglia ef al., 1976 ; Bag et al., 1975 ; Gabrielli et Baglioni, 1975 ; Wettenhall et al., 1976). Dans les cellules germinales, la traduction de certains RNA messagers stockés est déclenchée par la fertilisation, la germination ou le développement embryonnaire (Bhat et Padayatty, 1975 ; Spiegel et Marcus, 1975 ; Dworkin et Infante, 1976 ; Dworkin et al., 1977 ; Gabrielli ef al., 1977 ; Wood et Fitschen, 1978 ; Lifton ef al., 1976 ; Chen et Osborne, 1970 ; Young ef Raff, 1979 ; Dym et al., 1979). De la même façon, des cellules telles que les cellules épithéliales de l'oviducte et de la glande mammaire possèdent des RNA messagers pas ou peu traduits dans les stades précoces de la différenciation (Robins et Schimke, 1978 ; Pennequin et al., 1978 ; Houdebine, 1979). Dans la plupart des cellules des eucaryotes, il semble donc qu'il existe un équilibre entre les RNA messagers de diverses protéines, libres et engagés dans les polysomes, cet équilibre participant au contrôle de la quantité de protéine devant être élaborée dans une situation donnée (Spirin, 1978 ; Setyono et al., 1977 ; Geoghegan et al., 1979 ; Ovellette ef al., 1976). Ainsi dans les réticulocytes le RNA messager de la globine- $\alpha$, et non celui de la globine- $\beta$, existe à l'état libre associé à des protéines dans le cytoplasme. Cette répartition des deux RNA messagers semble être celle qui convient le mieux pour assurer une équimolarité des deux globines dans la cellule, étant donné les différences de vitesse de traduction de ces deux RNA messagers (Marbaix et al., 1976 ; Maundrell et al., 1979 ; Pavlakis et al., 1980). Les mécanismes qui président au recrutement des RNA messagers libres pour former un polysome ne sont en général pas connus. Pour le RNA messager de la ferritine hépatique, il a pu être déterminé que la présence de fer suffisaił à provoquer spécifiquement et réversiblement la traduction du RNA messager correspondant (Zähringer ef al., 1976a, b, c). Par opposition, le fer induit une augmentation de la quantité de transferrine synthétisée et sécrétée par le foie en activant la transcription du gène de la transferrine (McKnight ef al., 1980b). Dans d'autres cas, la disponibilité des acides aminés dans la cellule permet ou non le maintien des 
TABLEAU 1

Corrélation entre la concentration des mRNAs ef le taux de synthèse des protéines correspondantes

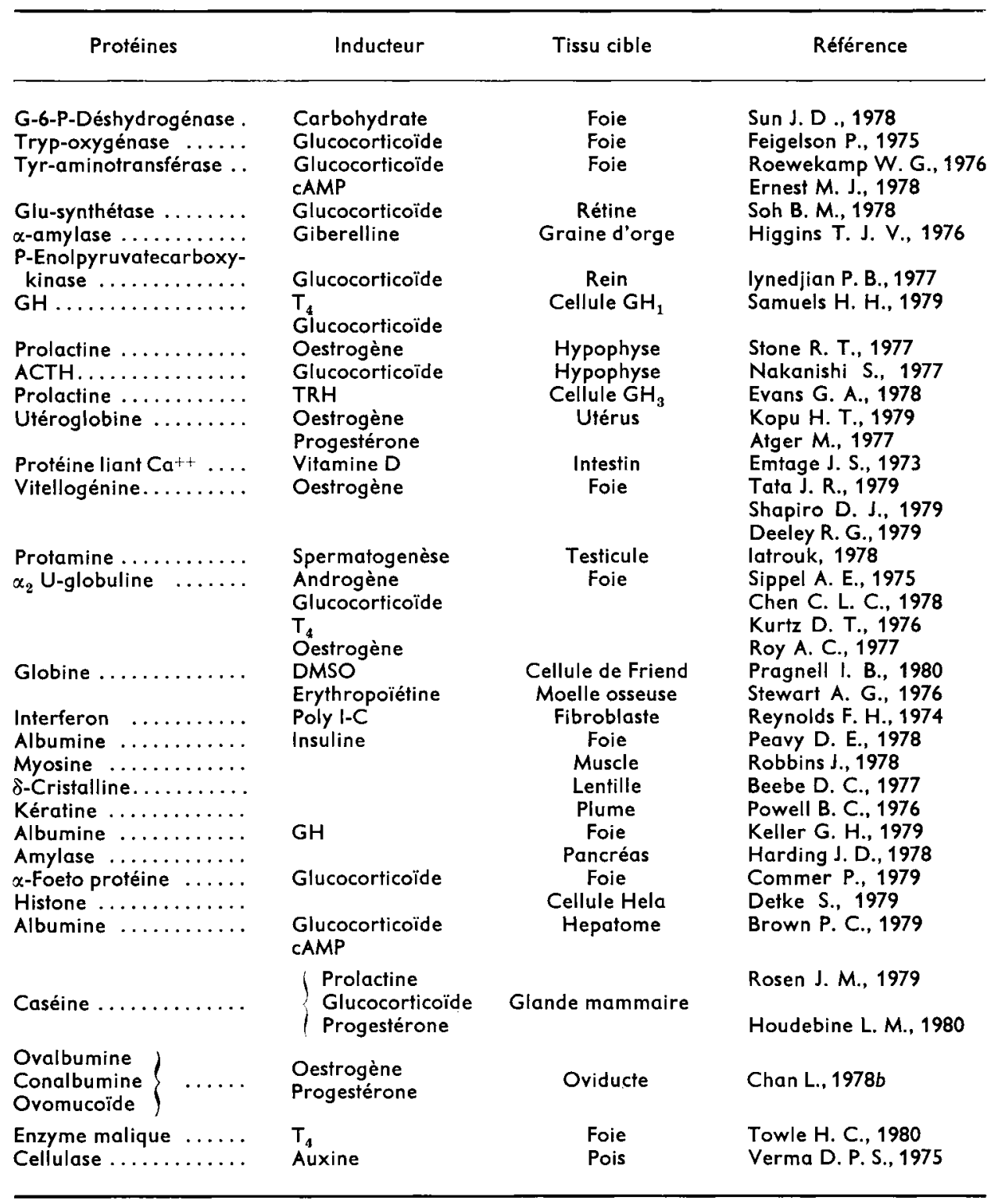

structures polysomales (Sonenshein et al., 1977 ; Yap et al., 1978). En règle générale, il semble qu'une activité cellulaire intense soit en relation avec la présence préférentielle des RNA messagers dans les polysomes (Rudland ef al., 1975 ; Jagus ef Kay, 1979). Ceci est particulièrement frappant dans le cas des cellules exportant des quantités 
massives de protéines (oviducłe, foie, glande mammaire, glande séricigène, etc...). De telles cellules ne peuvent pleinement remplir leur rôle que si elles possèdent en quantité suffisante les éléments ceiluiaires aspécifiquement impliqués dans la synthèse, la maturation et l'exportation des protéines : ribosomes, rRNA, AA-tRNA synthétase, facteurs d'initiation, d'élongation ef de terminaison de la traduction, appareil de Golgi, mitochondries, etc... (Shields, 1978). Les relations entre les mécanismes qui président à l'enrichissement simultané d'une cellule en facteurs de traduction et en RNA messagers spécifiques restent pour une large part inconnues. Par ailleurs, il est concevable que l'efficacité des éléments cellulaires impliqués dans la traduction soit modulée par des facteurs présents en quantité variable dans les cellules en fonction de leur situation (polyamines, ions, CAMP, etc...) ou par divers autres mécanismes (Ochoa et Haro, 1979). Enfin le degré de disponibilité en ATP peut dans certaines cellules telle la cellule mammaire qui consomme une part essentielle du glucose circulant (Kuhn, 1978), limiter la vitesse de polymérisation des acides aminés.

\section{III. - Le contrôle de la synthèse protéique pendant le développement.}

Il esł généralement admis que le développement embryonnaire qui suit la fertilisation s'accompagne d'un changement progressif du spectre des gènes exprimés répondant à la spécialisation des cellules que constiłuent les phénomènes de différenciation. Ce changement peut résulter de 2 types de mécanismes : 1) dans les stades très précoces du développement, peu de gènes sont exprimés et une activation progressive et sélective des gènes se produit au cours du développement, au fur et à mesure que la spécialisation de la cellule s'accentue ; 2 ) après fertilisation, les cellules sont totipotentes ef leur expression génétique s'appauvrit en se spécialisant au cours du développement. Dans le premier modèle, c'est le mécanisme classique induction-répression contrôlé en partie par les conditions extérieures qui assure essentiellement la sélection des gènes à transcrire. Dans le deuxième modèle au contraire, l'environnement des cellules qui varie au cours du développement est responsable d'une répression séquentielle et dans une certaine mesure irréversible des gènes qui ne devront pas s'exprimer dans la cellule différenciée. C'est ce deuxième modèle qui pour diverses raisons semble plutôt avoir actuellement la préférence (Caplan ef Ordahl, 1978). En effet, il a été observé que des noyaux transplantés dans des œufs fertilisés et anucléés ne pouvaient, le plus souvent, assurer efficacement un développement harmonieux et complet de l'organisme que si ces noyaux étaient issus de cellules encore peu différenciées (Gurdon, 1974). De même, la totipotentialité des cellules esł perdue dès la troisième division cellulaire et il n'exisłe aucune expérience réellement convaincante démontrant qu'une cellule est capable de se différencier et de récupérer tout ou partie des potentialités de la cellule embryonnaire. D'autre part, il a pu être établi que la diversité des RNA messagers présents dans une cellule d'oursin s'amenuisait au cours du développement embryonnaire (Kleene et Humphreys, 1977 ; Wold ef al., 1978). Cependant, c'est essentiellement la diversité des RNA messagers cytoplasmiques déterminanf la spécificité fonctionnelle d'une cellule qui est modifiée, par opposition aux séquences de RNA nucléaires dont la complexité varie peu. Dans cet ordre d'idées, il est remarquable que des séquences du RNA messager de globine aient pu être décelées 
dans les noyaux de cellules non érythroïdes (Humphries et al., 1976 ; Ono et Cutler, 1978 ; Perlman ef al., 1977 ; Therwath et Scherrer, 1978). La spécialisation des cellules semble donc correspondre à une perte progressive des capacités d'expression du génôme comprenant une répression quasi complète de certains gènes et une amplification de l'expression d'autres gènes spécifique de chaque type cellulaire. Certaines cellules paraissent échapper à ce genre de phénomène et dans un tissu, une très faible proportion de cellules incomplètement différenciées pourraient subsister. Ainsi s'explique peut-être le fait que, par exemple, quelques cellules synthétisant des protéines du blanc d'œuf et sensibles aux œstrogènes sont présentes dans le foie de Poulet (Tsai et al., 1979). Il convient cependant de considérer que ce phénomène est relativement marginal car des séquences de RNA messager de l'ovalbumine ne sont pas détectables dans plusieurs tissus du Poulet (Ono et Getz, 1980).

\section{IV. - Mécanismes de l'accumulation des RNA messagers.}

L'accumulation de RNA messagers spécifiques dans une cellule peut résulter de la mise en jeu de divers mécanismes plus ou moins indépendants : activation de la transcription des gènes, modification des processus post-transcriptionnels de maturation des pré-RNA messagers en RNA messagers actifs, stabilisation des RNA messagers.

A. - Activation des RNA polymérases. - La synthèse des RNA dans les cellules des eucaryotes est assurée par 3 types de RNA polymérase, I, II et III, impliqués respectivement dans la formation des RNA ribosomaux, des RNA messagers et des petits RNAs (†RNA, 5 s RNA, etc...) (Chambon, 1975). L'activité des RNA polymérase I et II

\section{TABLEAU 2}

Variations des activités RNA polymérase I ef II sous I'influence de divers inducteurs

\begin{tabular}{|c|c|c|}
\hline Agent stimulant & Tissu cible & Référence \\
\hline 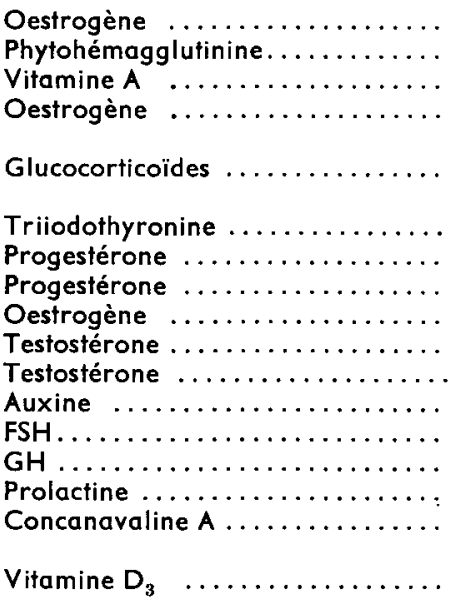 & $\begin{array}{c}\text { Oviducte } \\
\text { Lymphocite } \\
\text { Foie } \\
\text { Utérus } \\
\text { Thymus } \\
\text { Foie } \\
\text { Utérus } \\
\text { Oviducte } \\
\text { Foie } \\
\text { Prostate } \\
\text { Moelle osseuse } \\
\text { Soja } \\
\text { Testicule } \\
\text { Foie } \\
\text { Glande mammaire } \\
\text { Lymphocytes } \\
\text { Glande séricigène } \\
\text { Intestin }\end{array}$ & $\begin{array}{l}\text { Cox R. F., } 1976 \\
\text { Tillyer C. R., } 1978 \\
\text { Tsai C. H., } 1978 \\
\text { Courvalin J. C., } 1976 \\
\text { Bouton M. M., } 1977 \\
\text { Bell P. A., 1979 } \\
\text { Borthwick N. M., } 1978 \\
\text { Zoncheddu A., } 1977 \\
\text { Kokko E., } 1977 \\
\text { Müller W., } 1976 \\
\text { Mäenpää P. H., } 1976 \\
\text { Wang T. Y., } 1979 \\
\text { Valladares L. E., } 1976 \\
\text { Guilfoyle T. J., } 1975 \\
\text { Means A. R., } 1971 \\
\text { Spelsberg T. C., } 1976 \\
\text { Chomczynski P., } 1977 \\
\text { Land H., } 1977 \\
\text { Sridhara S., } 1976 \\
\text { Zerwekh J. E., } 1974\end{array}$ \\
\hline
\end{tabular}


a été évaluée dans diverses situations de stimulation de l'activité cellulaire, en particulier sous l'influence d'inducteurs hormonaux (tabl. 2). En général, les hormones possédant une activité trophique et une capacité à activer l'expression de certains gènes spécifiques, ne stimulent que très peu la RNA polymérase II responsable de la synthèse de RNA messagers ef plus significativement la RNA polymérase I. De plus, les activations de la RNA polymérase II sont souvent transitoires et semble-t-il peu en rapport avec des événements cellulaires connus. Par ailleurs, il n'est pas toujours tenu comple dans ces études qu'une fraction seulement des RNA polymérases cellulaires est vraisemblablement engagée dans la synthèse des RNA messagers. Les RNA polymérases sont en effet réparties entre le cytoplasme et les noyaux ef elles présentent des activités variables en fonction des conditions salines d'incubation (Courvalin ef al., 1976 ; Bouton et al., 1977). De plus, une augmentation de l'activité RNA polymérase II dans des noyaux isolés peuł correspondre aussi bien à une modification de l'activité matricielle de la chromatine qu'à une modification de l'activité polymérasique. Toutes ces considérations inclinent à penser que les variations d'activité RNA polymérase II ne constituent vraisemblablement pas un facteur déterminant dans les mécanismes d'activation de gènes spécifiques.

B. - Activation de la transcription de gènes spécifiques. - Il est aisément concevable que l'activation de la transcription des gènes constitue le moyen privilégié qu'une cellule peut utiliser pour assurer l'accumulation des RNA messagers. Relativement peu de cas ont encore pu être soumis à l'analyse. Une des limites expérimentales tient à la difficulté qu'il y a à distinguer les RNA réellement néosynthétisés de ceux déjà présents dans la cellule. Le taux de transcription a généralement été évalué en utilisant des

TABLEAU 3

Régulation de la transcription de gènes spécifiques

\begin{tabular}{|c|c|c|c|}
\hline Gène & Agent stimulant & Tissu cible & Réréfence \\
\hline 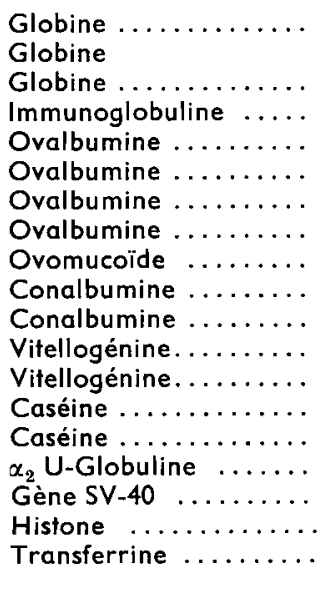 & $\begin{array}{l}\text { DMSO } \\
\text { DMSO } \\
\text { DMSO } \\
\text { Oestrogène } \\
\text { Oestrogène } \\
\text { Oestrogène } \\
\text { Oestrogène } \\
\text { Oestrogène } \\
\text { Oestrogène } \\
\text { Oestrogène } \\
\text { Oestrogène } \\
\text { Oestrogène } \\
\text { Prolactine } \\
\text { Prolactine } \\
\text { Interféron } \\
\text { Mitose } \\
\text { Oestrogène } \\
\text { Fer }\end{array}$ & $\begin{array}{l}\text { Cellule de Friend } \\
\text { Cellule de Friend } \\
\text { Cellule de Friend } \\
\text { Myélome } \\
\text { Oviducte } \\
\text { Oviducte } \\
\text { Oviducte } \\
\text { Oviducte } \\
\text { Oviducte } \\
\text { Oviducte } \\
\text { Oviducte } \\
\text { Foie } \\
\text { Foie } \\
\text { Glande mammaire } \\
\text { Glande mammaire } \\
\text { Foie } \\
\text { Cellule vero } \\
\text { Embryon d'oursin } \\
\text { Foie }\end{array}$ & $\begin{array}{l}\text { Lowenhaupt K., } 1979 \\
\text { Reff M. E., } 1979 \\
\text { Orkin S. H., } 1977 \\
\text { Smith M. M., } 1976 \\
\text { Nguyen-Huu M. C., } 1978 \\
\text { Nguyen-Huu M. C., } 1978 \\
\text { Tsai M. J., } 1978 \\
\text { Swaneck G. E., } 1979 \\
\text { Tsai M. J., 1978 } \\
\text { Nguyen-Huu M. C., } 1978 \\
\text { McKnight G. S., } 1979 \\
\text { Panyim S., 1978 } \\
\text { Mullinix K. P., } 1979 \\
\text { Guyette W. A., } 1979 \\
\text { Teyssot B., } 1980 \\
\text { Chan K. M., } 1978 \\
\text { Metż D. H., } 1977 \\
\text { Shutt R. H., } 1974 \\
\text { McKnight G. S., } 1980\end{array}$ \\
\hline
\end{tabular}


sondes DNA complémentaires des RNA messagers à éfudier. Ces sondes froides en excès peuvent s'hybrider à des RNA messagers néosynthétisés par des noyaux ou de la chromatine en présence du nucléotides marqués ou par des cellules entières en présence de nucléosides marqués. De même des sondes marquées peuvent s'hybrider à des $\mathrm{Hg}$. RNA néosynthétisés par des noyaux incubés en présence de $\mathrm{Hg}$. CTP et retenus sélectivement sur SH Sépharose. Dans la plupart des cas, l'accumulation d'un RNA messager s'accompagne d'une activation de la transcription du gène correspondant (tabl. 3).

C. - Stabilisation des RNA messagers. - S'il apparaît qu'une activation de la transcription d'un gène est effectivement souvent impliquée dans le mécanisme de contrôle de son expression, il est possible que la demi-vie d'un RNA messager varie en fonction du degré de stimulation de la cellule. Une stabilisation de certains RNA messagers peut représenter une économie pour une cellule différenciée non soumise à des pressions d'adaptation intense. Ainsi, l'accélération réversible de la transcription du gène de l'ovalbumine provoquée par les œestrogènes (Swaneck et al., 1979) ne semble pas représenter la totalité de l'action de l'hormone puisqu'une augmentation de la demi-vie du RNA messager est induite par le stéroïde (Palmifer et Carey, 1974; Cox, 1977 ; McKnight et Palmiter, 1979). Ce phénomène est beaucoup plus marqué dans le cas de la prolactine qui induit à la fois une accélération de la transcription des gènes des caséines et une stabilisation de leurs RNA messagers (Teyssot et Houdebine, 1980). De même, les glucocorticoïdes stabilisent le RNA messager de la glutamine synthétase (Goldman et Jones, 1977), mais pas celui de la tyrosine aminotransférase (Steinberg ef al., 1975a, b; Nickol et al., 1978). Par contre, le DMSO qui augmente la transcription du gène de globine dans les cellules de Friend, provoque en même temps un déstabilisation sélective du RNA messager de globine (Lowenhaupt et Lingrel, 1979). Les mécanismes moléculaires qui président au contrôle de la demi-vie des RNA messagers restent particulièrement méconnus.

D. - Le remodelage du génôme comme mode de régulation de l'expression des gènes. - Parmi les mécanismes qu'il est possible d'imaginer pour le contrôle de l'expression des gènes, divers remodelages éventuels du dénôme ont été envisagés. Il serait en effet concevable que pour assurer une accumulation importante d'un RNA messager, une cellule aif vu le nombre des gènes correspondants augmenter. Une telle amplification de gènes serait susceptible de se produire au cours du développement embryonnaire au moment où les tissus acquièrent leur spécificité, ou tout aussi bien plus tard grâce à l'intervention d'hormones au moment où les programmes définis chez l'embryon atteignent à leur pleine expression. Un nombre suffisamment grand de cas a maintenant éfé examiné pour qu'il soit possible de conclure que de tels mécanismes ne sont pas la règle. Ainsi, les gènes de l'ovalbumine (Sullivan ef al., 1973), des globines (Packman et al., 1972), de la vitellogénine (Jost et al., 1977), des caséines (Houdebine, 1977) et de la fibroïne (Gage et Manning, 1977) n'existent qu'en nombre très faible dans les cellules où ils s'expriment, tout comme dans les cellules où ils ne s'expriment pas. Certains gènes existent cependant sous forme de familles qui correspondent à des protéines dont la structure peut présenter de légères différences (Kindle ef Firtel, 1978 ; Arnheim et al., 1973 ; Kemp, 1975 ; Lockett et al., 1979 ; Bhat ef al., 1980 ; Wahli et Dawid, 1980 ; Tobin et al., 1980). Par contre, certains gènes comme celui des 
histones existent en grand nombre et sont regroupés dans le génôme (Kedes et al., 1975 ; Crawford et al., 1979). Il est permis de penser que l'existence d'un grand nombre de ces gènes favorise leur expression qui est induite brutalement, de manière intense et limitée à une période du cycle cellulaire. Pour les mêmes raisons, les RNA ribosomaux qui sont présents en quantité très abondante dans les cellules, puisqu'on admet généralement qu'ils représentent $80 \mathrm{p}$. 100 des RNA cellulaires, sont issus de gènes largement réitérés dans le génôme (Wellauer et Dawid, 1977). On peuł également considérer que les RNA ribosomaux, à l'inverse des RNA messagers, n'étant pas traduits et de ce fait l'expression des gènes des RNA ribosomaux ne bénéficiant pas de l'amplification que constitue la traduction, il soit alors nécessaire de synthétiser les produits directs de la transcription en relative abondance.

Il est donc remarquable que les gènes les plus étudiés jusqu'à ce jour qui sont parmi les plus intensément exprimés, n'aient pas vu leur nombre augmenter au cours de l'induction. Il serait cependant hâtif de conclure que le génôme est une entité figée. Il a été en effet rapporté récemment que sous la pression sélective intense du méthotrexate, des cellules cultivées pouvaient progressivement augmenter très considérablement ef de manière partiellement reversible le nombre des gènes de la dihydrofolate réductase pour assurer une accumulation de l'enzyme dans la cellule (Alt ef al., 1978). Le génôme serait donc doué d'une certaine plasticité. Il est vraisemblable que ce système n'est cependant pas généralisable pour diverses raisons, en particulier parce qu'il s'agit là d'un gène « domestique » et il serait sans doute imprudent de conclure que les cellules puissent aisément et couramment faire appel à ce genre de mécanisme.

Plus généralement, il est possible d'imaginer que la différenciation cellulaire résulte d'un remodelage de certaines régions du génôme, en relation directe ou non avec les gènes devant spécifiquement s'exprimer dans l'état différencié. Là encore, il semble qu'un tel mécanisme ne soit pas la règle. Un examen des fragments de DNA obtenus par digestion spécifique à l'aide d'enzymes de restriction à différents stades du développement de la drosophile, indique que les changements de structure primaire du DNA sont extrèmement rares (Potter ef Thomas, 1978). Par ailleurs, des noyaux extraits de lymphocyles de Xenope injectés dans des œufs enucléés peuvent conduire à un développement normal et avancé de l'embryon (Wabl et al., 1975), ce qui indique que le génôme n'a pas été irréversiblement modifié par la différenciation cellulaire. Dans le cas du gène de l'ovalbumine du Poulet dont la structure primaire a pu être examinée en détail, aucune différence n'a pu être décelée entre le DNA de l'oviducte et le DNA du foie.

Le cas particulier des gènes des immunoglobulines échappe cependant à cette règle. Des récents travaux ayanł permis la détermination de la structure fine de ces gènes ont fait apparaître que les immunoglobulines sont composées de six fragments correspondant à autant d'exons dans le DNA, dont certains vont former la partie constante et d'autres la partie variable de la protéine. Les exons sont relativement rapprochés dans le génôme des lymphocyłes différenciés. Par opposition, ils sont neffement plus éloignés les uns des autres dans le DNA embryonnaire (Seidman et al., 1979 ; Coleclough et al., 1980). Ces observations ont conduit à formuler une hypothèse expliquant l'infinie variété des anticorps : les parties constantes des immunoglobulines sont présentes en faible quantité dans le génôme (Hozumi et Tonegawa, 1976) ; les 
parties variables existent en grand nombre et constituent des familles ou sous-groupes qui se trouvent éloignés des parties constantes dans le DNA embryonnaire (Seidman et al., 1978) ; au cours de la différenciation, les parties variables se rapprochent des parties constantes et s'associent de diverses manières conduisant à la formation d'une multiłude de gènes d'immunoglobuline à partir de leurs éléments (Seidman et al., 1978 ; Dunnick, 1979). Un tel mécanisme n'est peut-être pas strictement réservé au cas des immunoglobulines et il pourrait refléter une des étapes clé dans la formation des gènes au cours de l'évolution.

E. - Les mécanismes du contrôle hormonal de l'expression des gènes. - L'expression de bon nombre de gènes est sous la dépendance d'informations extracellulaires qui sont elles-mêmes souvent portées par les hormones ou par divers autres facteurs circulant dans le sang et assimilables du point de vue mécanistique à des hormones. Ces hormones peuvent être classées en fonction de leur structure qui détermine probablement pour une large part leur mode d'action. Ainsi, il est généralement admis que les facteurs à structure stéroïdienne (œstrogène, androgène, progestagène, glucocorticoïde, vitamine $D_{3}, \ldots$ ) pénètrent dans la cellule où ils rencontrent un récepteur cytosolique. Après cette association, le complexe hormone-récepteur est transporté vers le noyau où il est censé agir en se liant à la chromatine. Un modèle relativement détaillé a ainsi été proposé pour le récepteur de la progestérone activant le gène de l'ovalbumine (Schwartz et al., 1977) : le récepteur progestérone serait composé de deux sousunités, l'une se liant directement au DNA et l'autre à des protéines de la chromatine. Un tel modèle extrapole globalement la notion d'inducteur-répresseur applicable au génôme bactérien. Divers arguments indiquent que le mode d'action des hormones stéroïdiennes est singulièrement plus complexe. Il est par exemple difficile d'expliquer pourquoi il existe un délai entre la pénétration du complexe hormone-récepteur dans le noyau ef l'activation de la transcription des gènes cibles (Palmiter et al., 1976 ; McKnight et Palmiter, 1979 ; Mulvihill et Palmiter, 1980 ; Nguyen-Huu et al., 1978). Il est par ailleurs frappant que le gène de la transferrine de Poulet qui est commun au foie et à l'oviducte et qui a pour inducteur dans les deux cas les ostrogènes, soit activé par le stéroïde d'une manière tout à fait différente dans ces deux types cellulaires (Lee ef al., 1978 ; McKnight et al., 1980). L'impact du complexe stéroïde-récepteur ne semble pas être ponctuel, car c'est une proportion importante de la chromatine qui change de conformation dans ces conditions (Johnson et al., 1979 ; Vic et al., 1978). Le changement de conformation de la chromatine est plus marqué pour les gènes activés par l'hormone, car ces gènes deviennent plus accessibles pour des nucléases ajoutées à la chromatine ou à des noyaux isolés (Axel et Garel, 1976 ; Bloom ef Anderson, 1979 ; Levitt ef al., 1979 ; Millet et al., 1978 ; Shepherd ef al., 1977). Ce phénomène semble assez général puisqu'il a pu être observé pour d'autres gènes tels que celui de la globine (Bloom et Anderson, 1979). Cependant une stricte corrélation entre le degré d'activité d'un gène et sa sensibilité vis-à-vis des activités nucléasiques n'a pas pu être établie dans le cas du gène de l'ovalbumine qui reste préférentiellement sensible à la DNAse I même après le retrait des œstrogènes (Shepherd ef al., 1977). La transmission de l'information hormonale dans la cellule cible ne paraît pas assurée seulement par le transfert du complexe stéroïde-récepteur dans le noyau. En effet, une inhibition de la synthèse protéique suffit à interrompre le message hormonal (McKnight, 
1978 ; Delap ef Feigelson, 1978 ; Chen ef Feigelson, 1979), ce qui suggère l'existence d'un relais intracellulaire dont la présence nécessite une synthèse protéique normale.

Les hormones thyroïdiennes pourraient agir selon des mécanismes ressemblant à ceux des hormones stéroïdiennes. Une différence majeure réside dans le fait que des récepteurs spécifiques de la triiodothyronine existent en permanence dans la chromatine, indépendamment de la présence de l'hormone (Oppenheimer, 1979). L'application de l'hormone thyroïdienne à une cellule cible induit comme pour les stéroïdes un changement de conformation de la chromatine vraisemblablement en relation avec l'activation de gènes spécifiques (Baxter et al., 1979).

Les hormones des cellules végétales telles que l'acide indolacétique possèdent également des récepteurs spécifiques dans la chromatine, ef leur mécanisme d'action pourrait être apparenté à celui des hormones thyroïdiennes (Roy et Biswas, 1977).

II est généralement admis que les hormones à structure protéique se fixent sur des récepteurs périphériques localisés sur la membrane plasmique. De cette fixation peuvent résulter 2 phénomènes : 1) la formation et la transmission de messages intracellulaires tels que le cAMP ; 2) l'endocytose du complexe hormone-récepteur. Aussi mulłiples que soient les rôles attribués au cAMP, il n'est de toute évidence pas le relais intracellulaire de toutes les hormones protéiques. Cependant le fait que le CAMP ou ses dérivés puissent favoriser l'accumulation de RNA messagers spécifiques suggère que ce nucléotide pourrait être le médiateur intracellulaire de certaines hormones agissant sur l'expression génétique (Ernest et Feigelson, 1978 ; Noguchi et al., 1978 ; Brown et Papaconstantinou, 1979 ; Kellems ef al., 1979).

L'endocytose du complexe membranaire hormone-récepteur peut avoir au moins 2 fonctions : 1) une distribution du complexe hormone-récepleur dans divers compartiments intracellulaires cibles ; 2) une dégradation du complexe conduisant elle-même soit à une désensibilisation de la cellule vis-à-vis de l'information hormonale, soit à la formation de messages intracellulaires qui pourraient être des fragments de la membrane ou de l'hormone endocytées.

Certaines hormones tels l'insuline (Golfine et al., 1978) ou le facteur de croissance du nerf (NGF) (Marchiosio et al., 1980) semblent arriver jusqu'au noyau, encore que ce fait ait été contesté dans le cas de l'insuline (Carpentier et al., 1979). Pour une hormone comme la prolactine que l'on sait activer la transcription des gènes des caséines, il n'existe pas d'arguments expérimentaux permettant d'affirmer que l'hormone est transférée massivement au noyau (Houdebine, 1980). Si l'endocytose du complexe hormone-récepteur est largement partagée par la plupart des hormones possédant un récepteur périphérique et en général par les ligands se fixant à des récepteurs spécifiques sur la membrane plasmique, la destruction du récepteur ou de l'hormone ne semble pas faire partie intégrante des mécanismes induisant des actions telles que la formation de progestérone via une accumulation de CAMP (Ascoli, 1978), la multiplication cellulaire (Maxfield et al., 1979 ; Savion et al., 1980) ou l'activation de gènes spécifiques (Houdebine et Djiane, 1980). Par ailleurs, la transmission de certaines informations depuis la membrane plasmique jusqu'aux gènes ne peut se faire normalement que si le cytosquelette a conservé son intégrité, comme le démontre l'action inhibitrice de la colchicine (Chen et al., 1976 ; Marks et al., 1978 ; Volpe, 1979 ; Houdebine et Djiane, 1980). 


\section{V. - Conclusions.}

Malgré les progrès très significatifs qui ont été réalisés ces dernières années dans la compréhension de mécanismes contrôlant la synthèse des protéines chez les eucaryołes, de nombreuses zones d'ombre persistent. Il est vraisemblable que les expérimentations vont se poursuivre dans deux directions convergentes : 1) l'étude des mécanismes de la transcription des gènes ; 2) la recherche de la nature ef du rôle des relais intracellulaires transmettant l'information extracellulaire jusqu'aux gènes. Nul doute que la possibilité qui est maintenant offerte d'amplifier, donc de posséder en quantité importante, des fragments donnés d'acide nucléique et de les séquencer, représente un moyen d'investigation d'une puissance considérable. II est en effet possible de déterminer la séquence primaire des gènes, de leur partie exprimée, des introns et surtout des portions précédant la séquence transcrite en RNA messagers où l'on peut s'attendre à trouver les sites de fixation des RNA polymérases ef les sites régulateurs éventuels (Gannon et al., 1979 ; Cochet et al., 1979 ; Schroeder et al., 1979 ; Benoist et al., 1980 ; Busslinger et al., 1980 ; Sures et al., 1980 ; Grosschedl et Birnstiel, 1980). Il est également envisageable de modifier la séquence nucléotidique de certaines régions des gènes et de les réintroduire dans des cellules afin de déterminer le rôle des séquences modifiées sur la formation des RNA messagers ef leur expression en protéine (Grosschedl et Birnstiel, 1980). La possession de fragments de DNA contenant des gènes connus permet la reconstitution de systèmes transcriptionnels acellulaires et partant, la détermination des mécanismes régulateurs (Wasylyk et Chambon, 1980). La mise en évidence d'une corrélation entre le degré de méthylation du DNA et l'activité d'un gène peut constituer une nouvelle voie d'approche dans l'étude du contrôle de l'expression génétique (Mandel et Chambon, 1979 ; Kuo et al., 1979). Des inconnues demeurent sur le rôle exact des introns dans les gènes et de l'intervention possible de la matrice nucléaire dans la maturation des RNA messagers et leur exportation dans le cytoplasme (Herman et al., 1978 ; Long ef al., 1979). Les changements de conformation que subit dans certaines conditions la chromatine lors d'une induction hormonale (Johnson ef al., 1979) suggèrent que de telles modifications peuvent représenter une part importante du mécanisme de contrôle de l'expression génétique, en modulant l'accessibilité des gènes aux RNA polymérases ou aux inducteurs eux-mêmes. II reste à déterminer les voies par lesquelles un RNA messager est spécifiquement plus ou moins stabilisé et plus ou moins quantitativement introduit dans un polysome. Il n'existe que relativement peu d'informations sur les mécanismes qui permettent une bonne coordination dans l'activation spécifique d'un groupe de gènes conduisant dans la même cellule à l'accumulation de RNA messagers et à la synthèse des protéines correspondantes dans une proportion harmonieuse. Dans certains types cellulaires, l'activation de gènes spécifiques s'accompagne de la mise en place de la machinerie cellulaire permettant la maturation ef l'exportation des protéines. L'existence de liens éventuels entre ces phénomènes reste à déterminer.

Bien qu'une somme considérable de travaux relatifs au mécanisme d'action des hormones stéroïdiennes aient été effectués, le rôle exact du récepteur de l'hormone reste encore une énigme (Chan et al., 1978b). Une part essentielle des informations perçues par la cellule par l'intermédiaire des récepteurs de la membrane plasmique 
est transmise aux gènes par l'intervention probable de relais intracellulaires totalement inconnus. Les données récentes sur la structure de la membrane cellulaire périphérique et sur le rôle de ses éléments constitutifs devraient permettre d'accroître les possibilités d'investigation dans ce domaine (Edelman, 1976 ; Nirolson, 1976 ; Bourguignon et Singer, 1977 ; Harwood et al., 1978 ; Davies ef al., 1980 ; Goldstein et al., 1979).

La majeure partie des travaux relatifs à l'étude du contrôle de l'expression génétique utilisent des systèmes biologiques dans lesquels un inducteur vient moduler le degré d'expression d'un gène. Aussi spectaculaires que soient parfois les effets produits, ils ne doivent pas faire oublier le fait que l'intervention d'un inducteur se réduit souvent à amplifier l'expression d'un programme sélectionné lors de la différenciation embryonnaire. Les mécanismes moléculaires qui permettent cette sélection sont essentiellement inconnus et l'expérimentation dans ce domaine risque de rester encore longtemps plutôt malaisée.

6e Réunion du groupe Développement I.N.R.A., Clermont-Ferrand/Theix, 22-23 mai 1980.

\section{References}

ALT F. W., KELLEMS R. E., BERTINO J. R., SCHIMKE R. T., 1978. Selective multiplication of dihydrofolate reductase genes in methotroxate-resistant variants of culture murine cells. J. biol. Chem., 253, 1357-1370.

ARNHEIM N., HINDENBURG A., BEGG G. S., MORGAN F. J., 1973. Multiple genes for lysosome in birds. J. biol. Chem., 248, 8036-8042.

ASCOLI M., 1978. Demonstration of a direct effect of inhibitors on the degradation of receptor-bound human chorionic gonadotropin on the steroidogenic pathway. J. biol. Chem., 253, 7839-7843.

ATGER M., MILGROM E., 1977. Progesterone induced mRNA. Translation, purification and preliminary characterization of uteroglobin mRNA. J. biol. Chem., 252, 5412-5418.

AXEL R., GAREL A., 1976. Structure of specific genes in chromatin. Progr. nucl. Ac. Res. mol. Biol., 19, 335-341.

BAG J., SARKAR S., 1975. Cytoplasmic non polysomal messenger ribonucleoprotein containing action messenger RNA in chicken embryogenic muscles. Biochemistry, 14, 3800-3807.

BAXTER J. D., EBERHARDT N. L., APRILETTI J. W., JOHNSON L. K., IVARIE R. D., SCHECHTER B. S., MORRIS J. A., SEEBURG P. H., GOODMAN H. M., LATHAM K. R., POLANSKY J. R., MARTIAL J. A., 1979. Thyroid hormone receptors and responses. Recent Progr. Horm. Res., 35, 97-153.

BEEBE D. C., PIATIGORSKY J., 1977. The control of $\delta$-cristallin gene expression during lens cell development. Develop. Biol., 59,174-182.

BEGGS J. D., VANDEN BERG J., VAN OOYEN A., WEISSMANN C., 1980. Abnormal expression of chromosomal rabbit*-globin gene in Saccharomyces Cerevisiae. Nature, 283, 835-840.

BELL P. A., BORTHWICK N. M., 1979. Regulation of transcription in rat thymus cells by glucocorticoids. J. Steroid Biochem., 11, 381-387.

BENOIST C., O'HARE K., BREATHNACH R., CHAMBON P., 1980. The ovalbumin gene sequence of putative control regions. Nucl. Ac. Res., 8, 127-142.

BHAT S. P., JONES R. E., SULLIVAN M. A., PIATIGORSKY J., 1980. Chicken lens cristalline-DNA sequences show at least two $\delta$-cristallin genes. Nature, 284, 234-238.

BHAT S. P., PADAYATTY J. D., 1975. Transcriptional events during early phase of germination of rice embryos. Nature, 256, 227-228.

BLOOM K. S., ANDERSON J. N., 1979. Conformation of ovalbumin and globin genes in chromatin during differential gene expression. J. biol. Chem., 254, 10532-10539. 
BORTHWICK N. M., BELL P. A., 1978. Glucocorticoid regulation of rat thymus RNA polymerase activity : the role of RNA and protein synthesis. Mol. cell. Endocr., 9, 269-278.

BOURGUIGNON L. Y. W., SINGER S. J., 1977. Transmembrane interactions and the mechanism of capping on surface receptors by their specific ligands. Proc. Nat. Acad. Sci. USA, 74, 5031-5035.

BOUTON M. M., COURVALIN J. C., BAULIEU E. E., 1977. Effect of estradiol on rat uterus DNAdependent RNA polymerases. J. biol. Chem., 252, 4607-4612.

BREATHNACH R., MANDEL J. L., CHAMBON P., 1977. Ovalbumin gene is split in chicken DNA. Nature, 270, 314-319.

BREATHNACH R., MANTEI N., CHAMBON P., 1980. Correct splicing of a chicken ovalbumin gene transcript in mouse $L$ cells. Proc. nat. Acad. Sci. USA, 77, 740-744.

BROWN P. C., PAPACONSTANTINOU J., 1979. Coordinated modulation of albumin synthesis and mRNA levels in cultured hepatoma cells by hydrocortisone and cAMP analogs. J. biol. Chem., 254, 9379-9384.

BUCKINGHAM M. E., GROS F., 1975. The use of metrizamide to separate cytoplasmic ribonucleoprotein particles in muscle cell cultures. FEBS Letters, 53, 355-359.

BUSSLINGER M., PORTMANN R., IRMINGER J. C., BIRNSTIEL M. L., 1980 . Ubiquitous and genespecific regulatory $5^{\prime}$ sequences in a sea urchin histone DNA clone coding for histone protein variants. Nucl. Ac. Res., 8, 957-977.

CAPLAN A. I., ORDAHL C. P., 1978. Irreversible gene repression model for control of development. Science, 201, 120-130.

CARPENTIER J. L., GORDEN P., FREYCHET P., LE CAM A., 1979. Lysosomal association of internalized 125|-insulin in isolated rat hepatocytes. J. clin. Invest., 63, 1249-1261.

CHAMBON P., 1975. Eucaryotic nuclear RNA polymerases. Ann. Rev. Biochem., 44, 613-638.

CHAN K. M., KURTZ D. T., FEIGELSON P., 1978a. Transcription of the $\alpha_{2}$ u-globulin gene in male rat liver nuclei in vitro. Biochemistry, 17, 3092-3096.

CHAN L., MEANS A. R., O'MALLEY B. W., 1978b. Steroid hormone regulation of specific gene expression. Vifamins Hormones, 36, 259-295.

CHEN C. L. C., FEIGELSON P., 1978. Glucocorticoid induction of $\alpha_{2}$ u-globulin protein synthesis and its mRNA in rat hepatocytes in vitro. J. biol. Chem., 253, 7880-7885.

CHEN C. L. C., FEIGELSON P., 1979. Cycloheximide inhibition of hormonal induction of $\alpha_{2}$ u-globulin mRNA. Proc. nat. Acad. Sci. USA, 76, 2669-2673.

CHEN D., OSBORNE D. J., 1970. Hormones in the translational control of early germination in wheat embryos. Nafure, 226, 1157-1160.

CHEN K., HELLER J., CANNELAKIS E. S., 1976. Studies on the regulation of ornithine decarboxylase activity by the microtubules: the effect of colchicine and vinblastine. Biochem. biophys. Res. Commun., 68, 401-407.

CHOMCZYNSKI P., SOKOL-MISIAK N., KLECZKOWSKA D., 1977. Activity of DNA-dependent RNA polymerases in rabbit mammary gland during lactogenesis. FEBS Letfers, 76, 191-194.

COCHET M., GANNON F., HEN R., MAROTEAUX L., PERRIN F., CHAMBON P., 1979. Organisation and sequence studies of the 17-piece chicken conalbumin gene. Noture, 282, 567-572.

COLECLOUGH C., COOPER D., PERRY R. P., 1980. Rearrangement of immunoglobulin heavy chain genes during B-lymphocyte development as revealed by studies of mouse plasmocytoma cells. Proc. nat. Acad. Sci. USA, 77, 1422-1426.

COMMER P., SCHWARTZ C., TRACY S., TAMAOKI T., CHIU J. F., 1979. Dexamethasone inhibits $\alpha$-foeto protein gene expression in developping mouse liver. Biochem. biophys. Res. Commun., 89, 1294-1299.

COURVALIN J. C., BOUTON M. M., BAULIEU E. E., NURET P., CHAMBON P., 1976. Effect of estradiol on rat uterus DNA dependent RNA polymerases. J. biol. Chem., 251, 4843-4849.

COX R. F., 1976. Quantification of elongating form A and B RNA polymerases in chick oviduct nuclei and effects of estradiol. Cell, 7, 455-465.

COX R. F., 1977. Estrogen with drawal in chick oviduct. Selective loss high abundance classes of polyadenylated messenger RNA. Biochemistry, 16, 3433-3443.

CRAIK C. S., BUCHMAN S. R., BEYCHOK S., 1980. Characterization of globin domains : heme binding to the central exon product. Proc. not. Acad. Sci. USA, 77, 1384-1388.

CRAWFORD R. J., KRIEG P., HARVEY R. P., HENISH D. A., WELLS J. R. E., 1979. Histone gene are clustered with a 15-kilobase repeat in the chicken genome. Nature, 279, 132-136. 
CRICK F., 1979. Split genes and RNA splicing. Science, 204, 264-271.

DARNELL J. E., 1978. Implications of RNA splicing in evolution of eucaryotic cells. Science, $202,1257-$ 1260.

DAVIDSON E. H., KLEIN W. H., BRITTEN R. J., 1977. Sequence organization in animal DNA and a speculation on Hn RNA as a coordinate regulatory transcript. Develop. Biol., 55, 69-84.

DAVIES P. J. A., DAVIES D. R., LEVITZKI A., MAXFIELD F. R., MILHAUD P., WILLINGHAM M. C., PASTAN I. H., 1980. Transglutaminase is essential in receptor-mediated endocytosis of $\alpha_{2}$-macroglobulin and polypeptide hormones. Nature, 283, 162-167.

DAWID I. B., WAHLI W., 1979. Application of recombinant DNA technology to questions of developmental biology : a review. Develop. Biol., 69, 305-328.

DEELEY R. G., GOLDBERGER R. F., 1979. Regulation of expression of the vitellogenin gene in avian liver, 291-307. In HAMILTON T. H., CLARK J. H., SADLER W. A., Ontogeny of receptors and reproductive hormone action. Raven Press.

DELAP L., FEIGELSON P., 1978. Effect of cycloheximide on the induction of tryptophan oxygenase mRNA by hydrocortisone in vivo. Biochem. biophys. Res. Commun., 82, 142-149.

DETKE S., LICHTLER A., PHILLIPS I., STEIN J., STEIN G., 1979. Reassessment of histone gene expression during cell cycle in human cells by using homologous $\mathrm{H}_{4}$ histone cDNA. Proc. nat. Acad. Sci. USA, 76, 4995-4999.

DOOLITTLE F. W., 1978. Genes in pieces : were they even together. Nofure, 272, 581-582.

DUNNICK W., 1979. Joining immunoglobulin genes. Nature, 281, 253-254.

DWORKIN M. B., INFANTE A. A., 1976. Relationship between the mRNA of polysomes and free ribonucleoprotein particles in the early sea urchin embryo. Develop. Biol., 53, 73-90.

DWORKIN M. B., RUDENSEY L. M., INFANTE A. A., 1977. Cytoplasmic non polysomal ribonucleoprotein particles in sea urchin embryos and their relationship to protein synthesis. Proc. nat. Acad. Sci. USA, 74, 2231-2235.

DYM H. P., KENNEDY D. S., HEYWOOD S. M., 1979. Sub-cellular distribution of the cytoplasmic myosin heavy chain mRNA during myogenesis. Differentiation, 12, 145-155.

EDELMAN G. M., 1976. Surface modulation in cell recognition and cell growth. Science, 192, $218-228$.

EMTAGE J. S., LAWSON D. E. M., KODICEK E., 1973. Vitamin D-induced synthesis of mRNA for calcium binding protein. Nature, 246, 100-101.

ERNEST M. J., FEIGELSON P., 1978. Increase in hepatic tyrosine amino transferase mRNA during enzyme induction by $\mathrm{N}^{6}, \mathrm{O}^{2}$-dibutyryl cyclic AMP. J. biol. Chem., 253, 319-322.

EVANS G. A., DAVID D. N., ROSENFELD M. G., 1978. Regulation of prolactin and somatotropin mRNA by thyroliberin. Proc. nat. Acad. Sci. USA, 75, 1294-1298.

FEIGELSON P., BEATO M., COLMAN P., KALIM M., KILLEWICH L. A., SCHUTZ G., 1975. SIudies on the hepatic glucocorticoid receptor and on the hormonal modulation of specific mRNA levels during enzyme induction. Recent Progr. Horm. Res., 31, 213-241.

GABRIELLI F., BAGLIONI C., 1975. Maternal messenger RNA and histone synthesis in embryos of the surf clam Spisula solidissimo. Develop. Biol., 43, 254-263.

GABRIELLI F., BAGLIONI C., 1977. Regulation of maternal mRNA translation in developping embryos of the surf clam Spisula solidissima. Nature, 269, 529-531.

GAGE L. P., MANNING R. F., 1976. Determination of the multiplicity of the silk fibroin gene and detection of fibroin gene related DNA in the genome of Bombyx Mori. J. mol. Biol., 101, 327-348.

GANNON F., O'HARE K., PERRIN F., LE PENNEC J. P., BENOIST C., COCHET M., BREATHNACH R., ROYAL A., GARAPIN A., CAMI B., CHAMBON P., 1979. Organisation and sequences at the $5^{\prime}$ end of a cloned complete ovalbumin gene. Nafure, 278, 428-434.

GEDAMU L., DIXON G. H., 1976. Assay of protamine messenger RNA from rainbow trout festis. J. biol. Chem., 251, 1446-1554.

GEDAMU L., DIXON G. H., DAVIES P. L., 1977. Identification and isolation of protamine messenger ribonucleoparticles from rainbow trout testis. Biochemistry, 16, 1383-1391.

GEOGHEGAN T., CEREGHINI S., BRAWERMAN G., 1979. Inactive mRNA-protein complexes from mouse sarcoma- 180 ascites cells. Proc, nat. Acad. Sci. USA, 76, 5587-5591.

GILBERT W., 1978. Why genes in pieces. Noture, 271, 501.

GOLDMAN B. M., JONES R. E., 1977. Postranscriptional stabilization of glutamine synthetase messenger RNA. J. cell Biol., 75, 349a. 
GOLDSTEIN J. L., ANDERSON R. H. W., BROWN M. S., 1979. Coated pits, coated vesicles and receptor mediated endocytosis. Nature, 279, 679-685.

GOLDFINE I. D., 1978. Insulin receptors and the site of action of insulin. Life Sciences, 23, 2639-2648.

GOODMAN H. M., OLSON M. V., HALL B. D., 1977. Nucleotide sequence of a mutant eukaryotic gene. Proc, nat. Acod. Sci. USA, 74, 5453-5457.

GROSSCHEDL R., BIRNSTIEL M. L., 1980. Identification of regulatory sequences in the prelude sequences of an $\mathrm{H}_{2} \mathrm{~A}$ histone gene by the study of specific deletion mutants in vivo. Proc. nat. Acod. Sci. USA, 77, 1432-1436.

GUILFOYLE T. J., LIN C. Y., CHEN Y. M., NAGAO R. T., KEY J. L., 1975. Enhancement of soybean RNA polymerase I by auxin. Proc. nat. Acad. Sci. USA, 72, 69-72.

GURDON J. B., 1974. The confrol of gene expression in animal development. Harvard Univ. Press, Cambridge, Mass.

GUYETTE W. A., MATUSIK R. J., ROSEN J. M., 1979. Prolactin mediated transcriptional and posttranscriptional control of casein gene expression. Cell, 17, 1013-1023.

HALBREICH A., PAJOT P., FOUCHER M., GRANDCHAMP C., SLONIMSKI P. P., 1980. A pathway of cytochrome $b$ mRNA processing in yeast mitochondria : specific splicing steps and an intronderived circular DNA. Cell, 19, 321-329.

HAMER D. H., LEDER P., 1979a. Splicing and formation of stable RNA. Cell, 18, 1299-1302.

HAMER D. H., LEDER P., 1979b. Expression of chromosomal mouse $\beta$-globin gene cloned SV 40. Nature, 281, 35-40.

HAMER D. H., SMITH K. D., BOYER S. H., LEDER P., 1979. SV 40 recombinants carrying rabbif $\beta$-globin gene coding sequences. Cell, 17, 725-735.

HARDING J. D., RUTTER W. J., 1978. Rat pancreatic amylase mRNA. J. biol. Chem., 253, 8736-8740.

HARPOLD M. M., DOBNER P. R., EVANS R., BRANCOFT F. C., DARNELL J. E., 1979. The synthesis and processing of a nuclear RNA precursor to rat pregrowth hormone messenger RNA. Nucl. Ac. Res., 6, 3133-3143.

HARWOOD J. P., CONTI M., CONN P. M., DUFAU M. L., CATT K. J., 1978. Receptor regulation and target cell responses : studies in the ovarian luteal cells. Mol. cell. Endocr., 11, 121-135.

HERMAN R., WEYMOUTH L., PENMAN S., 1978. Heterogeneous nuclear RNA-proteins fibers in chromatin-depleted nuclei. J. Cell Biol., 78, 663-674.

HIETER P. A., LEGENDRE S. M., LEVY C. C., 1976. Stabilization of an RNA molecule by 3 '-terminal poly A-induced inhibition of RNAse activity. J. biol. Chem., 251, 3287-3293.

HIGGINS T. J. V., ZWAR J. A., JACOBSEN J. V., 1976. Giberellic acid enhances the level of translatable mRNA for $\alpha$-amylase in barley aleurone layers. Nature, 260, 166-168.

HOROWITZ J. M., LAUB O., BRATOSIN S., ALONI Y., 1978. Splicing of SV 40 late mRNA is a posttranscriptional process. Nature, 275, 558-559.

HOUDEBINE L. M., 1977. $\alpha s_{1}$ and $\beta$-gene frequencies in ewe and cow genome. Biochimie, 59, 659-660.

HOUDEBINE L. M., 1979. Role of prolactin in the expression of casein genes in the virgin rabbit. Cell Differ. 8, 49-59.

HOUDEBINE L. M., 1980. Role of prolactin, glucocorticoids and progesterone in the control of casein gene expression. In DUMONT J. E., NUNEZ J., Hormones and cell regulation, Vol. 4, 175-196. Elsevier/North Holland, Biomed Press.

HOUDEBINE L. M., DJIANE J., 1980. Effects of lysosomotropic agents and of microfilaments and microtubule-disrupting drugs on the activation of casein gene expression by prolactin in the mammary gland. Mol. cell. Endocr., 17, 1-15.

HOZUMI N., TONEGAWA S., 1976. Evidence for somatic rearrangement of immunoglobulin genes coding for variable and constant region. Proc. nat. Acad. Sci. USA, 73, 3628-3832.

HUMPHRIES S., WINDASS J., WILLIAMSON R., 1976. Mouse globin gene expression in erythoid and non-erythoid tissues. Cell, 7, 267-277.

IATROV K., SPIRA A. W., DIXON G. H., 1978. Protamine mRNA : evidence for early synthesis and accumulation during spermatogenesis in rainbow trout. Develop. Biol., 64, 82-98.

INEDJIAN P. B., HANSON R. W., 1977. mRNA for renal phosphoenol carboxykinase. J. biol. Chem., 252, 8398-8403.

JACQ C., LAZOWSKA J., SLONIMSKI P. P., 1980. Sur un nouveau mécanisme de la régulation de l'expression génétique. C. R. Acad. Sci. Paris, sér. D, 290, 89-92. 
JAGUS R., KAY J. E., 1979. Distribution of lymphocyte messenger RNA during stimulation by phytohaemnagglutunin. Eur. J. Biochem., 100, 503-510.

JEFFRYES A. J., FLAVELL R. A., 1977. The globin gene contains a large insert in the coding sequence. Cell, 12, 1097-1108.

JOHNSON L. K., LAN N. C., BAXTER J. D., 1979. Stimulation and inhibition of cellular functions by glucocorticoids. Correlations with rapid infiuences on chromatin structures. $)$. biol. Chem., 254, 7785-7794.

JOST J. P., SCHUERCH A. R., WALZ A., 1977. Reiteration frequency of vitellogenin gene in avian liver before and after estradiol treatment. FEBS Leffers, 75, 133-137.

KEDES L. H., COHN R. H., LOWRY J. C., CHANG C. Y., COHEN S. N., 1975. The organization of sea urchin histone gene. Cell, 6, 359-369.

KELLEMS R. E., MORHENN V. B., PFENDT E. A., ALT F. W., SCHIMKE R. T., 1979. Polyma virus and cyclic AMP-mediated control of dihydrofolate reductase $\mathrm{mRNA}$ abundance in methotroxate-resistant mouse fibroblasts. J. biol. Chem., 254, 309-318.

KELLER G. H., TAYLOR J. M., 1979. Effect of hypophysectomy and GH treatment ovalbumin mRNA levels in rat liver. J. biol. Chem., 254, 276-278.

KEMP D. J., 1975. Unique and repetitive sequences in multiple genes of feather keratin. Nature, 254, 573-577.

KINDLE K. L., FIRTEL R. A., 1978. Identification and analysis of Dictyostelium actin genes, a family of moderately repeated genes. Cell, 15, 763-778.

KINNINBURGH A. J., MERTZ J. E., ROSS J., 1978. The precursor of mouse $\beta$-globin messenger RNA contains two intervening RNA sequences. Cell, 14, 681-693.

KINNINBURGH A. J., ROSS J., 1979. Processing of the mouse $\beta$-globin mRNA precursor. Cell, 17, 915-921.

KLEENE K. C., HUMPHREYS T., 1977. Similarity of $H_{n}$ RNA sequences in blastula and pluteus stage sea urchin embryos. Cell, 12, 143-155.

KNAPP G., BECKMANN J. S., JOHNSON P. F., FUHRMAN S. A., ABELSON J., 1978. Transcription and processing of intervening sequences in yeast tRNA genes. Cell, 14, 221-236.

KOKKO E., ISOMAA V., JÄNNE O., 1977. Progesterone-regulated changes in transcriptional events in rabbit uterus. Biochim. biophys. Acta, 479, 354-366.

KOLATA G. B., 1980. Genes in pieces. Science, 207, 392-393.

KOPU H. T., HEMMINK I. S., FORKELI T. K., JÄNNE O., 1979. Hormonal control of uteroglobin secretion in rabbit uterus. Biochem. J., 180, 491-500.

KOZAK M., 1979. Inability of circular mRNA to attach to eucaryotic ribosomes. Nature, 280, 82-85.

KUHN N. J., 1978. Glucose as a fuel for the mammary gland. Biochem. Soc. Trans., 6, 539-543.

KUO M. T., MANDEL J. L., CHAMBON P., 1979. DNA methylation : correlation with DNAse sensitivity of chicken ovalbumin and conalbumin chromatin. Nucl. Ac. Res., 7, 2105-2113.

KURTZ D. T., SIPPEL A. E., FEIGELSON P., 1976. Effect of thyroid hormones on the level of hepatic mRNA for $\alpha_{2}$ u-globulin. Biochemistry, 15, 1031-1036.

KWAN S. P., WOOD T. G., LINGREL J. B., 1977. Purification of a putative precursor of globin messenger RNA from mouse nucleated erythoid cells. Proc. nat. Acad. Sci. USA, 74, 178-182.

LAI E. C., WOO S. L. C., BORDELON-RISER M. E., FRASER T. H., O'MALLEY B. W., $1980 . \quad$ Ovalbumin is synthesized in mouse cells transformed with the natural chicken ovalbumin gene. Proc. nat. Acad. Sci. USA, 77, 244-248.

LAND H., SCHAFER K. P., 1977. In vitro synthesis and stability of RNA in isolated nuclei from bovine lymphocytes. Biochem. biophys. Res. Commun., 79, 947-956.

LEDER A., MILLER H., HAMER D., SEIDMAN J. G., NORMAN B., SULLIVAN M., LEDER P., 1978. Comparison of cloned mouse $\alpha$ - and $\beta$-genes : conservation of intervening sequence locations and extragenic homology. Proc. nat. Acad. Sci. USA, 75, 6187-6191.

LEE D. C., MCKNIGHT G. S., PALMITER R. D., 1978. The action of estrogen and progesterone on the expression of the transferrin gene. J. biol. Chem., 253, 3494-3503.

LEVITT A., AXEL R., CEDAR H., 1979. Nick translation of active genes in intact nuclei. Develop. Biol., 69, 496-505.

LIFTON R. P., GOLBERG M. L., KARP R. W., HOGNESS D. S., 1978. The organization of the histone genes in Drosophila Melanogaster. Cold Spring Harbor Symp. quant. Biol., 42, 1047-1051.

LIFTON R. P., KEDES L. H., 1976. Size and sequence homology of masked maternal and embryonic histone messenger RNAs. Develop. Biol., 48, 47-55. 
LOCKETT T. J., KEMP D. J., ROGERS G. E., 1979. Organization of the unique and repetifive sequences in feather keratin messenger RNA. Biochemistry, 18, 5654-5663.

LONG B. H., HUANG C. Y., POGO O., 1979. Isolation and characterization of the nuclear matrix in Friend erythroleukemia cells : chromatin and $H_{n}$ RNA interactions with the nuclear matrix. Cell, 17, 1079-1090.

LOWENHAUPT K., LINGREL J. B., 1978. A change in the stability of globin mRNA during the induction of murine erythroleukemia cell. Cell, 14, 337-344.

LOWENHAUPT K., LINGREL J. B., 1979. Synthesis and furnover of globin mRNA in murine erythroleukemia cells induced with hemin. Proc. nat. Acad. Sci. USA, 76, 5173-5177.

MCKEOWN M., TAYLOR W. C., KINDLE K. L., FIRTEL R. A., BENDER W., DAVIDSON N., 1978. Multiple heterogenous actin genes in Dictyostelium. Cell, 15, 789-800.

McKNIGHT G. S., 1978. The induction of ovalbumin and conalbumin mRNA by estrogen and progesterone in chick oviduct explant cultures. Cell, 14, 403-413.

MCKNIGHT G. S., LEE D. C., HEMMAPLARDH D., FINCH C. A., PALMITER R. D., 1980a. Transferrin gene expression. Effect of nutritional iron deficiency. J. biol. Chem., 255, 144-147.

MCKNIGHT G. S., LEE D. C., PALMITER R. D., 1980b. Transferrine gene expression. Regulation of mRNA transcription in chick liver by steroid hormones and iron deficiency. J. biol. Chem., 255, 148-153.

MCKNIGHT G. S., PALMITER R. D., 1979. Transcriptional regulation of the ovalbumin and conalbumin genes by steroid hormones in chick oviduct. J. biol. Chem., 254, 9050-9058.

MÄENPÄÄ P. H., 1976. Vifellogenin synthesis in rooster liver : changes in liver polyribosomes in relation to the activation of nucleolar RNA polymerase and vitellogenin synthesis. Biochem. biophys. Res. Commun., 72, 347-354.

MANDEL J. L., CHAMBON P., 1979. DNA methylation : organ specific variations in the methylation pattern within and around ovalbumin and other chicken genes. Nucl. Ac. Res., 7, 2081-2104.

MANTEI N., BOLL W., WEISSMANN C., 1979. Rabbit $\beta$-globin mRNA production in mouse $L$ cells transformed with cloned rabbit $\beta$-globin chromosomal DNA. Nafure, 281, 40-46.

MARBAIX G., HUEZ G., NOKIN P., CLEUTER Y., 1976. Free cyloplasmic $\alpha$-globin messenger RNA appears during the maturation of rabbit reficulocytes. FEBS Leffers, 66, 269-273.

MARCHISIO P. C., NALDINI L., CALISSANO P., 1980. Intracellular distribution of new growth factor in rat pheochromocytoma PC 12 cells : evidence for a perinuclear and intranuclear location. Proc. not. Acad. Sci. USA, 77, 1656-1660.

MARKS A., MAHONY J. B., BROWN I. R., 1978. Colchicine inhibits the accumulation of messenger RNA for a brain specific protein in rat glial cells. Biochem. biophys. Res. Commun., 82, 13061313.

MAUNDRELL K., MAXWELL E. S., CIVELLI O., VINCENT A., GOLDENBERG S., BURI J. F., IMAIZUMI-SCHERRER M. T., SCHERRER K., 1979. Messenger ribonucleoprotein complexes in avian erythroblasts : carriers of post-transcriptional regulation. Mol. Biol. Rep., 5, 43-51.

MAXFIELD F. R., DAVIES P. J. A., KLEMPNER L., WILLINGHAM M. C., PASTAN I. H., 1979. Epidermal growth factor stimulation of DNA synthesis is potentiated by compounds that inhibits its clustering in coated pits. Proc. nat. Acad. Sci. USA, 76, 5731-5735.

MEANS A. R., 1971. Concerning the mechanism of FSH action : rapid stimulation of testicular synthesis of nuclear RNA. Endocrinology, 89, 981-989.

MELTON D. A., DEROBERTIS E. M., CORTESE R., 1980. Order and intracellular location of the events involved in the maturation of a spliced tRNA. Nature, 284, 143-148.

METZ D. H., OXMAN M. N., LEVIN M. J., 1977. Interferon inhibits the in vitro accumulation of virus specific RNA in nuclei isolated from SV 40 infected cells. Biochem. biophys. Res. Commun., 75, $172-178$.

MILLER D. M., TURNER P., NIENHUIS A. W., AXELROD D. E., GOPALAKRISHNAN T. V., 1978. Active conformation of the globin genes in uninduced and induced mouse erythroleukemia cells. Cell, 14, 511-521.

MULLER W. E. G., ZAHN R. K., 1976. Poly ADP-ribosylation of DNA-dependent RNA polymerase I from quail oviduct. Dependence on progesterone stimulation. Mol. cell. Biochem., 12, 147-159.

MULLIGAN R. C., HOWARD B. H., BERG P., 1979. Synthesis of rabbit $\beta$-globin in cultured monkey kidney cells following infection with SV $40 \beta$-globin recombinant genome. Nafure, 277, 108-114. 
MULLINIX K. P., MEYERS M. B., CHRISTMANN J. K., DEELEY R. G., GORDON J. I., GOLBERGER R. F., 1979. Specific transcription in chicken liver chromatin by endogenous RNA polymerase II. J. biol. Chem., 254, 9860-9866.

MULVIHILL E. R., PALMITER R. D., 1980. Relationship of nuclear progesterone receptors to induction ovalbumin and conalbumin mRNA in chick oviduct. J. biol. Chem., 255, 2085-2091.

NAKANISHI S., KITA T., TAH S., IMURA H., NUMA S., 1977. Glucocorticoid effect on the level of corticotropin mRNA activity in rat pituitary. Proc. nat. Acad. Sci. USA, 74, 3283-3286.

NGUYEN-HUU M. C., BARRETT K. J., GIESECKE K., WURTZ T., SIPPEL A. E., SCHÜTZ G., 1978a. Transcription of the chicken ovalbumin and conalbumin gene during early secondary inducfion with estrogens. Hoppe Seyler's Z. Physiol. Chem., 359, 1307-1313.

NGUYEN-HUU M. C., SIPPEL A. E., HYNES N. E., GRONER B., SCHÜTZ G., 1978b. Preferential transcription of the ovalbumin gene in isolated hen oviduct nuclei by RNA polymerase $B$. Proc. nat. Acad. Sci. USA, 75, 686-690.

NICKOL J.M., LEE K. L., KENNEY F. T., 1978. Changes in hepatic levels of tyrosine amino transferase messenger RNA during induction by hydrocortisone. J. Biol. Chem., 253, 4009-4015.

NICOLSON G. L., 1976. Transmembrane control of the receptors on normal and fumor cells. Biochim. biophys. Acta, 457, 57-108.

NILSSON M. O., HULTIN T., 1975. Pol A-containing cytoplasmic RNA in dormant cysts of Arfemia Solina. FEBS Lefters, 52, 269-272.

NOGUCHI T., DIESTERHAFT M., GRANNER D., 1978. Dibutyryl cyclic AMP increases the amount of functional messenger RNA coding for tyrosine amino-transferase in rat liver. J. biol. Chem., 253, 1332-1335.

NUDEL U., SORE Q. H., LITTAUER U. Z., MARBAIX G., HUEZ G., LECLERCQ M., HUBERT E., CHANTRENNE H., 1976. Globin mRNA species containing poly A segments of different lengths. Then functional stability in Xenopus oocytes. Eur. J. Biochem., 64, 115-121.

NUNBERG J. H., KAUFMAN R. J., CHANG A. C. Y., COHEN S. N., SCHIMKE R. T., 1980. Structure and genomic organization of the mouse dihydrofolate reductase gene. Cell, 19, 355-364.

OCHOA S., HARO C., 1979. Regulation of protein synthesis in eucaryotes. Ann. Rev. Biochem., 48, 549-580.

O'HARE K., BREATHNACH R., BENOIST C., CHAMBON P., 1979. No more than seven interruptions. in the ovalbumine gene : comparison of genomic and double-stranded CDNA sequences. Nucl. Ac. Res., 7, 321-334.

OPPENHEIMER J. H., 1979. Thyroid hormone action at the cellular level. Science, 203, 971-979.

ONO T., CUTLER R. G., 1978. Age-dependent relaxation of gene expression : increase of oncogenous murine leukemia virus-related and globin-related RNA in brain and liver of mice. Proc. nat. Acad. Sci. USA, 75, 4431-4435.

ONO T., GETZ J., 1980. Levels of ovalbumin messenger RNA sequences in non oviduct tissues of the chicken. Develop. Biol., 75, 481-484.

ORKIN S. H., SWERDLOW P. S., 1977. Globin RNA synthesis in vitro by isolated erythroleukemic cell nuclei. Proc. nat. Acad. Sci. USA, 74, 2475-2479.

OUELLETTE A. J., KUMAR A., MALT R. A., 1976. Physical aspects and cytoplasmic distribution of messenger RNA in mouse kidney. Biochim. biophys. Acta, 425, 384-395.

PACKMAN S., AVIV H., ROSS J., LEDER P., 1972. A comparison or globin genes in duck reticulocytes and liver cells. Biochem. biophys. Res. Commun., 49, 813-819.

PAGLIA L. M., KASTERN W. H., BERRY S. J., 1976. Messenger ribonucleoprotein particles in silkmoth oogenesis. Develop. Biol., 51, 182-189.

PALMITER R. D., CAREY N. H., 1974. Rapid inactivation of ovalbumin messenger RNA after acute withdrawal of estrogen. Proc. nat. Acad. Sci. USA, 71, 2357-2361.

PALMITER R. D., MOORE P. B., MULVIHILL E. R., EMTAGE S., 1976. A significant lag in the induction of ovalbumin messenger RNA by steroid hormones : a receptor translocation hypothesis. Cell, 8, 557-572.

PANYIM F., OHNO T., JOST J. P., 1978. In vitro RNA synthesis and expression of vitellogenin gene in isolated chicken liver nuclei. Nucl. Ac. Res., 5, 1353-1370.

PAVLAKIS G. N., LOCKARD R. E., VAMVAKOPOULOS N., RIESER L., RAJBHANDARY U. L., VOURNAKIS J. N., 1980. Secondary structure of mouse and rabbit $\alpha$ - and $\beta$-globin mRNAs : differential accessibility of $\alpha$ - and $\beta$-initiator AUG towards nuclease. Cell, 19, 91-102. 
PEAVY D. E., TAYLOR J. M., JEFFERSON L. S., 1978. Correlation of albumin production rates and albumin mRNA levels in livers of normal, diabetic and insulin-treated diabetic rats. Proc. not. Acad. Sci. USA, 75, 5879-5883.

PELLICER A., WIGLER M., AXEL R., SILVERSTEIN S., 1978. The transfer and stable integration of the HSV thymidine kinase gene into mouse cells. Cell, 14, 133-141.

PENNEQUIN P., ROBINS D. M., SCHIMKE R. T., 1978. Regulation of translation of ovalbumin messenger RNA by estrogens and progesterone in oviduct of withdrawn chicks. Eur. $J$. Biochem., $90,51-58$.

PERLMAN S. M., FORD P. J., ROSBASH M. M., 1977. Presence of tadpole and adult globin RNA sequences in oocytes of Xenopus laevis. Proc. nat. Acad. Sci. USA, 74, 3835-3839.

PETRISSANT G., 1981. Le contrôle de l'initiation chez les eucaryotes. Reprod. Nutr. Develop. 21, $163-171$.

POTTER S. S., THOMAS C. A., 1978. The two-dimension fractionation of Drosophila DNA. Cold Spring Harbor Symp. quant. Biol., 42, 1023-1031.

POWELL B. C., KEMP D. J., PARTINGTON G. A., GIBBS P. E. M., ROGERS G. E., 1976. Control of feather keratin synthesis by the availability of keratin mRNA. Biochem. biophys. Res. Commun., 68, $1263-1271$.

PRAGNELL I. B., ARNDT-JOVIN D. J., JOVIN T. M., FAGG B., OSTERTAG W., 1980. Commitment to differentiation in friend cells and initiation of globin mRNA synthesis occurs during the $G_{1}$ phase of the cell cycle. Exp. Cell Res., 125, 459-470.

REFF M. E., DAVIDSON R. L., 1979. In vitro DNA dependent synthesis of globin RNA sequences from erythroleukemic cell chromatin. Nucl. Ac. Res., 6, 275-287.

REYNOLDS F. H., PITHA P. M., 1974. The induction of interferon and its mRNA in human fibroblasts. Biochem. biophys. Res. Commun., 59, 1023-1030.

ROBBINS J., HEYWOOD S. M., 1978. Quantification of myosin heavy-chain mRNA during myogenesis. Eur. J. Biochem., 82, 601-608.

ROBINS D. M., SCHIMKE R. T., 1978. Differential effects estrogen and progesterone on ovalbumin mRNA utilization. J. biol. Chem., 253, 8925-8934.

ROEWEKAMP W. G., HOFER E., SEKERIS C. E., 1976. Translation of mRNA from rat liver polysomes into tyrosine amino transferase and tryplophan oxygenase in a protein synthesizing system from wheat germ. Eur. J. Biochem., 70, 259-268.

ROOP D. R., NORDSTROM J. L., TSAI S. Y., TSAI M. J., O'MALLEY B. W., 1978. Transcription of structural and intervening sequences in the ovalbumin gene and identification of a potential ovalbumin mRNA precursors. Cell, 15, 671-685.

ROOP D. R., TSAI M. J., O'MALLEY B. W., 1980. Definition of the $5^{\prime}$ and $3^{\prime}$ ends of transcripts of the ovalbumin gene. Cell, 19, 63-68.

ROSEN J. M., GUYETTE W. A., MATUSIK R. J., 1979. Hormonal regulation of casein gene expression in the mammary gland, 249-279. In HAMILTON T. H., CLARK J. H., SADLER W. A., Ontogeny of receptors and reproductive hormone action, Raven Press.

ROSS J., 1976. A precursor of globin messenger RNA. J. mol. Biol., 106, 403-420.

ROY P., BISWAS B. B., 1977. A receptor protein for indolacefic acid from plant chromatin and its role in transcription. Biochem. biophys. Res. Commun., 74, 1597-1605.

ROY P., DOWBENKO D. J., SCHIOP M. J., 1977. Studies on the mode of oestrogenic inhibition of hepatic synthesis of $\alpha_{2} \mathrm{u}$-globulin and its corresponding mRNA in rat liver. Biochem. J., 164, 91 97.

ROYAL A., GARAPIN A., CAMI B., PERRIN F., MANDEL J. L., LEMEUR M., BREGEGEGRE F., GANNON F., LE PENNEC J. P., CHAMBON P., KOURILSKY P., 1979. The ovalbumin gene region : common feature in the organization of three genes expressed in chick oviduct under hormonal control. Nature, 279, 125-132.

RUDLAND P. S., WEIL S., HUNTER A. R., 1975. Changes in RNA metabolism and accumulation of presumptive messenger RNA during transition from the growing to the quiescent state of cultured mouse fibroblasts. J. mol. Biol., 96, 745-766.

RYFFEL A. U., WYLER T., MUELLENER D. B., WEBER R., 1980. Identification, organization and processing intermediates of the putative precursors of Xenopus vitellogenin messenger RNA. Cell, 19, 53-61.

SALDITT-GEORGIEFF M., HARPOLD M., CHEN-KIANG S., DARNELL J. E., 1980. The addition of 5' cap structures occurs early in $H_{n}$ RNA synthesis and prematurely terminated molecules are capped. Cell, 19, 69-79. 
SAMUELS H. H., STANLEY F., SHAPIRO L. E., 1979. Control of growth hormone synthesis in cultured $\mathrm{GH}_{1}$ cells by $3,5,3^{\prime}$ triiodo-L-thyronine and glucocorticoid agonists and antagonists. Biochemistry, 18, 715-721.

SAVION N., VLODAVSKY I., GOSPODAROWICZ D., 1980. Role of degradation process in the mitogenic effect of epidemial growth factor. Proc. nat. Acod. Sci. USA, 77, 1466-1470.

SCANGOS G. A., HUTTNER K. M., SILVERSTEIN S., RUDDLE F. H., 1979. Molecular analysis of chromosome-mediated gene transfer. Proc. nat. Acad. Sci. USA, 76, 3987-3900.

SCHAFFNER W., KUNG G., DEATWYER H., TELFORD J., SMITH H. O., BIRNSTIEL M. L., 1978. Genes and spacers of cloned sea urchin histone DNA analyzed by sequencing. Cell, 14, 655671.

SCHERRER K., 1973. Messenger RNA in eucaryotic cells : the life history of duck globin messenger RNA. Acta endocr., suppl., 95-129.

SCHERRER K., IMAIZUMI-SCHERRER M. T., REYNAUD C. A., THERWATH A., 1979. On premessenger RNA and transcriptions. A review. Mol. biol. Reprod., 5, 5-28.

SCHROEDER H. W., LIARAKOS C. D., GUPTA R. C., RANDERATH K., O'MALLEY, B. W., 1979. Ribosome binding site analysis of ovalbumin messenger RNA. Biochemistry, 18, 5798-5808.

SCHWARTZ R. J., CHANG C., SCHRADER W. T., O'MALLEY B. W., $1977 . \quad$ Effect of progesterone receptors on transcription. Ann. N. Y., Acad. Sci., 286, 147-160.

SEIDMAN J. G., LEDER A., NAU M., NORMAN B., LEDER P., 1978. Antibody diversity. Science, 202, 11-17.

SEIDMAN J. G., MAX E. E., LEDER P., 1979. A $x$-immunoglobulin gene is formed by site-specific recombination without further somatic mutation. Noture, 280, 370-375.

SETYONO B., GROSSMANN M., LIAUTRAD J. B., 1977. Evidence that proteins bound to the polysomal messenger RNA exist also free in the cytoplasm of Hela cells. Biochimie, 59, 43-49.

SHAPIRO D. J., BAKER H. J., 1979. Estrogen regulation of Xenopus laevis vitellogenin gene expression, 309-330. In HAMILTON T. H., CLARK J. H., SADLER W. A., Ontogeny of receptors and reproductive hormone action. Raven Press, New York.

SHEPHERD J. H., MULVIHILL E. R., PALMITER R. D., 1977. No change in DNAse I sensitivity of the ovalbumin gene during steroid hormone modulation of obalbumin synthesis. J. Cell Biol., 75, $353 a$.

SHIELDS R., 1978. Pleiofypic effects of hormones. Nature, 276, 440-441.

SHUTT R. H., KEDES L. H., 1974. Synthesis of histone mRNA sequences in isolated nuclei of cleavage stage sea urchin embryos. Cell, 3, 283-290.

SIPPEL A. E., FEIGELSON P., ROY A. K., 1975. Hormonal regulation of the hepatic mRNA levels for $\alpha_{2}$ u-globulin. Biochemistry, 14, 825-829.

SLONIMSKI P. P., 1980. Elements hypothétiques de l'expression des gènes morcelés: protéines messagères de la membrane nucléaire. C. R. Acod. Sci. Paris, sér. D, 290, 331-334.

SMITH M. M., HUANG R. C. C., 1976. Transcription in vitro of immunoglobulin kappa light chain genes in isolated mouse myeloma nuclei and chromatin. Proc. nat. Acad. Sci. USA, 73, 775-779.

SOH B. M., SARKAR P. K., 1978. Control of glutamine synthetase mRNA by hydrocortisone in the embryonic retina. Develop. Biol., 64, 316-328.

SONENSHEIN G. E., BRAWERMAN G., 1977. Entry of mRNA into polysomes during recovery from starvation in mouse sarcoma 180 cells. Eur. J. Biochem., 73, 307-312.

SPELSBERG T. C., WILSON J. T., 1976. Growth hormone and drug metabolism. Biochem. J., 154, 439448.

SPIEGEL S., MARCUS A., 1975. Polyribosome formation in early wheat embryo germination independent of either transcription or polyadenylation. Nalure, 256, 228-230.

SPIRIN A. S., 1978. Eucaryotic messenger RNA and informosomes. FEBS Leffers, 88, 15-17.

SRIDHARA S., PORTIER M. M., DAILLIE J., 1977. RNA polymerase and RNA synthesis in the silk glands of the silkworm Bombyx mori. Eur. J. Biochem., 72, 335-339.

STEINBERG R. A., LEVINSON B. B., TOMKINS G. M., 1975a. Superinduction of tyrosine amino transferase by actinomycin $D$ : a reevaluation. Cell, 5, 29-35.

STEINBERG R. A., LEVINSON B. B., TOMKINS G. M., 1975b. Kinetics of steroid induction an deinduction of tyrosine amino transferase synthesis in cultured hepatoma cells. Proc. nat. Acad. SCi. USA, 72, 2007-2011.

STEWART A. G., GLISSORD P. M., ARNSTEIN H. R. V., 1976. The initiation of globin synthesis in differentiating rabbit-bone marrow erythroid cells. Eur. J. Biochem., 66, 349-355. 
STONE R. T., MAVRER R. A., GORSKI J., 1977. Effect of estradiol-17 $\beta$ on pre-prolactine mRNA activity in the rat pituitary gland. Biochemistry, 16, 4915-4920.

SULLIVAN D., PALACIOS R., STAVNEZER J., TAYLOR J. M., FARAS A. J., KIELY M. L., SUMMERS N. M., BISHOP J. M., SCHIMKE R. T., 1973. Synthesis of a deoxyribonucleic acid sequence complementary to ovalbumin messenger RNA and quantification of ovalbumin genes. $J$. biol. Chem., 248, 7350-7539.

SUN J. D., HOLTEN D., 1978. Levels of raf liver glucose-6-phosphate dehydrogenase messenger RNA. J. biol. Chem., 253, 6832-6836.

SURES I., LEVY S., KEDES L. H., 1980. Leader sequences Strongylocentrofus purpuratus histone mRNAs start at a unique heptanucleotide common to all five histone genes. Proc. nat. Acad. Sci. USA, 77, 1265-1269.

SWANECK G. E., NORDSTROM J. L., KREVZALER F., TSAI M. J., O'MALLEY B. W., 1979. Effect of estrogen on gene expression in chicken oviduct : evidence for a transcriptional control of ovalbumin gene. Proc. nat. Acad. Sci. USA, 76, 1049-1053.

TATA J. R., SMITH D. F., 1979. Vitellogenesis : a versatile model for hormonal regulation of gene expression. Recent Progr. Horm. Res., 35, 47-95.

TEYSSOT B., HOUDEBINE L. M., 1980. Role of prolactin in the transcription of $\beta$-casein and $28 \mathrm{~S}$ ribosomal genes in the rabbit mammary gland. Eur. J. Biochem. 110, 263-272.

THERWATH A.,'SCHERRER K., 1978. Post-transcriptional suppression of globin gene expression in cells transformed by avian erythroblastosis virus. Proc. nat. Acad. Sci., USA, 75, 3776-3780.

TILLYER C. R., BUTTERWORTH P. H. W., 1978. The relationship between the activities of different pools of RNA polymerase I and II during PHA-stimulation of human lymphocytes. Nucl. Ac. Res., 5, 2099-2111.

TOBIN S. L., ZULAUF E., SANCHEZ F., CRAIG E. A., MCCARTHY B. J., 1980. Multiple actin-related sequences in the Drosophila melanogaster genome. Cell, 19, 121-131.

TOWLE H. C., MARIASH C. N., OPPENHEIMER J. H., 1980. Changes in the hepatic levels of mRNA for malic enzyme during induction by thyroid hormone or diet. Biochemistry, 19, 579-585.

TSAI C. H., CHYTIL F., 1978. Effect of vitamin A deficiency on RNA synthesis in isolated rat liver nuclei Life Sci., 23, 1461-1472.

TSAI S. Y., ROOP D. R., TSAI M. J., STEIN J. P., MEANS A. R., O'MALLEY B. W., 1978. Effect of estrogen on gene expression of chick oviduct. Regulation of the ovomucoid gene. Biochemistry, 17, 5773-5780.

TSAI M. J., TSAI S. Y., CHANG C. W., O'MALLEY B. W., 1978. Effect of estrogen on gene expression in the chick oviduct. Biochim. biophys. Acta, 521, 689-707.

TSAI S. Y., TSAI M.J., LIN C. T., O'MALLEY B. W., 1979. Effect of estrogen on ovalbumin gene expression in differentiated non target tissues. Biochemistry, 18, 5726-5731.

VALENZUELA P., VENEGAS A.,WEINBERG F., BISHOP R., RUTTER W. J., 1978. Structure of yeast phenylalanine tRNA genes : an intervening DNA segment within the region-coding for the tRNA. Proc. nat. Acod. Sci. USA, 75, 190-194.

VALLADARES L. E., CANAS P. E., MINGUELL J. J., 1976. Bone marrow RNA polymerase. Effect of testosterone on nucleotide incorporation into nuclear RNA. Nucl. Ac. Res., 3, 3077-3086.

VERMA D. P. S., MALLACHAN G. A., BYRNE H., EWINGS D., 1975. Regulation and in vitro translation of mRNA for cellulase from auxin-treated pea epicotyls. J. biol. Chem., 250, 1019-1026.

VIC P., GARCIA M., ANDRE J., HUMEAU C., ROCHEFORT H., 1978. Effet précoce de l'cestradiol sur l'ultrastructure de la chromatine dans l'endomètre et les tumeurs mammaires hormonodépendantes. C. R. Acad. Sci. Paris, sér. D, 287, 141-144.

VOLPE J. J., 1979. Microtubules and the regulation of 3-hydroxy-3-methyl glutamyl coenzyme $A$ reductase. J. biol. Chem., 254, 2568-2571.

WABL M. R., BRUN R. B., DU PASQUIER L., 1975. Lymphocytes of the toac Xenopus have the gene set for promoting tadpole development. Science, 190, 1310-1312.

WAHLI W., DAWID I. B., 1980. Isolation of two closely related vitellogenin genes, including their flanking regions from a Xenopus laevis gene library. Proc. nat. Acad. Sci. USA, 77, 1437-1441.

WANG T. Y., LOOR R. M., 1979. Testosterone-activated RNA synthesis in isolated prostate nuclei. J. Ster. Biochem., 10, 299-304.

WASYLYK B., CHAMBON P., 1980. Studies on the mechanism of transcription of nucleosomal complexes. Eur. J. Biochem., 103, 219-226. 
WELLAUER P. K., DAWID I. B., 1977. The structural organization in Drosophila melanogaster. Cell, 10, 193-212.

WETTENHALL R. E. H., SLOBBE A., HIGGINS T. J. V., 1976. Evidence for the presence of mRNA in the post-ribosomal cytoplasm of sheep lymphocytes. Biochim. biophys. Acta, 432, 312-322.

WIGLER M., PELLICER A., SILVERSTEIN S., AXEL R., 1978. Biochemical transfer of single copy eucaryotic genes using total cellular DNA as donor. Cell, 14, 725-731.

WIGLER M., SILVERSTEIN S., LEE L. S., PELLICER A., CHENG A., CHENG Y. C., AXEL R., 1977. Transfer of purified Herpes virus thymidine kinase gene to culture mouse cells. Cell, 11, 223 232.

WIGLER M., SWEET R., SIM G. K., WOLD B., PELLICER A., LACY E., MANIATIS T., SILVERSTEIN S., AXEL R., 1979. Transformation of mammalian cells with genes from procaryotes and eucaryotes. Cell, 16, 777-785.

WOLD B. J., KLEIN W. H., HOUGH-EVANS B. R., BRITTEN R. J., DAVIDSON E. H., 1978. Sea urchin embryo mRNA sequences expressed in the nuclear RNA of adult tissues. Cell, 14, 941 950.

WOLD B., WIGLER M., LACY E., MANIATIS T., SILVERSTEIN S., AXEL R., 1979. Introduction and expression of rabbit $\beta$-globin gene in mouse fibroblasts. Proc. not. Acad. Sci. USA, 76, 5684-5688.

WOOD D. E., FITSCHEN W., 1978. The mobilization of maternal histone messenger RNA after fertilization of the sea urchin egg. Cell Differ., 7, 103-114.

YAP S. H., STRAIR R. K., SHAFRITZ D. A., 1978. Identification of albumin mRNPs in the cytosol of fasting rat liver and influence of tryptophan or a mixture of aminoacids. Biochem. biophys. Res. Commun., 83, 427-433.

YOUNG E. M., RAFF R. A., 1979. Messenger ribonucleoprotein particles in developing sea urchin embryos. Develop. Biol., 72, 24-40.

ZAHRINGER J., BALIGA B. S., MUNRO H. N., 1976a. Subcellular distribution of total poly A-containing RNA and ferritin-mRNA in the cytoplasm of rat liver. Biochem. biophys. Res. Commun., 68, 1088-1093.

ZAHRINGER J., BALIGA B. S., MUNRO H. N., 1976b. Increased levels of microsomal albumine mRNA in the liver of nephrotic rats. FEBS Letters, 62, 322-325.

ZAHRINGER J., BALIGA B. S., MUNRO H. N., 1976c. Novel mechanism for translational control in regulation of ferritin synthesis by iron. Proc. nat. Acad. Sci. USA, 73, 857-861.

ZERWEKH J. E., HAUSSLER M. R., LINDELL T. J., 1974. Rapid enhancement of chick intestinal DNAdependent RNA polymerase Il activity by $1 \alpha_{1} 25$-dihydrovitamin $D_{3}$ in vivo. Proc. nat. Acad. Sci. USA, 71, 2337-2341.

ZIFF E. B., EVANS R. M., 1978. Coincidence of the promoter and capped 5 ' terminus of RNA from the adenovirus 2 major late transcription unit. Cell, 15, 1463-1475.

ZONCHEDDU A., VIARENGO A., ACCOMANDO R., FUGASSA E., ORUNESU M., 1977. Increased RNA polymerase activity in isolated liver nucleoli from thyroidectomized rats treated with triiodothyronine. Endocrinology, 101, 209-214. 